\title{
SMITHSONIAN LIBRARIES
}





\section{1,4 \\ $B 32$ \\ 1890 \\ MAA

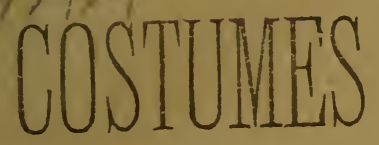

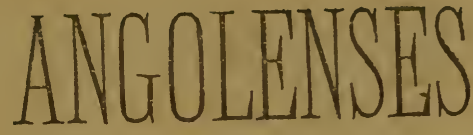

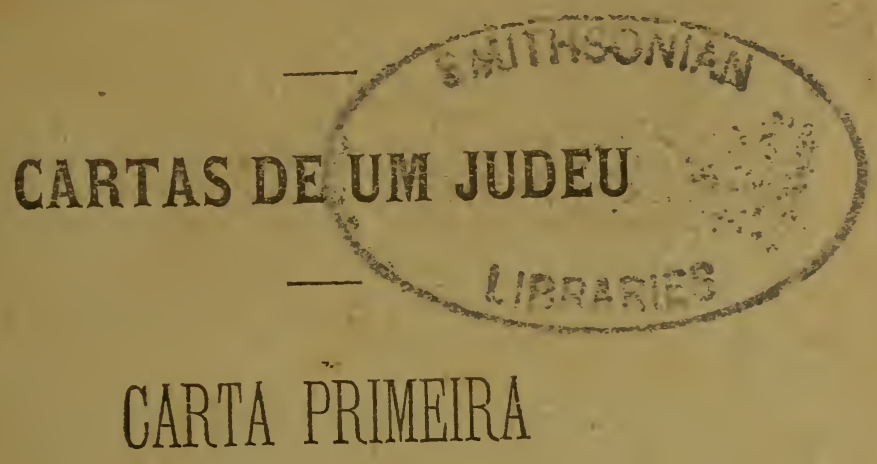

Loanda, 31 de Julho de 1876.

Meu born amigo

Lá diz o antigo rifão: o promettido ẻ devido.

Mal pensavas tu, quando uma noite no botequim do Martinho (noite memoravel por ter sido a da nossa ultima partida de radrez), me convidavas a ser teu iuformador, ou melhor, correspondente technico de toda e qualquer localidade onde me achasse, que o teu desejo havia de se realisar!

Sabiamos n'esse tempo que os meus negocios se tinham afundido. Tu, que bem me conheces, ao vêres-me pagar na integra todos os compromissas para com os meus credores, mal me restando dinbeiro para as primeiras necessidades do dia seguinte, conheceste que não me poderia mais subtrahir á fatalidade que pesa sobre todos os da minha raça - caminhar, caminhar.

Não te posso contar o que se passou depois d'essa noite para mim de saudosa memoria! Sei que me apartei de ti com os olhos $n_{-}-$jodos de lagrimas, como quem previa que a separaçau seria duradoura.

Effectivamente desesperado, vagueei pelas ruas e praçass de Lisboa, toda essa immensa noite, á procura... aabes de 
quê? De uma idéa com que podesse ligar o meu passado brilhante com o futuro desgraçado que se me antolhava.

Vi a bacia do Tejo, esse quasi Oceano da Europa. Vinha chegando a madrugada: e o pinheiral de mastros, que a pouco e pouco melhor se iam desenhando, fascinou-me! Quem sabe se o que n'essa occasião se passou em mim, não foi identico ao que se passaria no coração dos mais antigos navegadores da Peninsula! Reatei todas as tradições que andam ligadas á minha raça, sempre persistente a despeito da já antiquis. sima historia das nossas perseguições.

$O$ aspecto do Tejo, com seu vastissimo ancoradouro, e a vida que a pouco e pouco se ia desenvolvendo á proporção que a claridade de mais em mais irradiava; o cruzar dos botes, Ianchas e faluas em todas as direcções, o fumegar das chaminés a bordo dos paquetes que tinham entrado durante a noite, ou que accendiam caldeiras, prestes a sahir, tudo isso me inebriou os sentidos.

O mar! o mar tem uma gloriosa tradição para Portugal, e ainda mais particularmente para a raça israelita da Peninsula!

A Historia desdobrou-se-me ante o espirito já de si bem exaltado, pelo embate de tantos golpes através de uma vida ainda tão curta!

Toda a importancia historica d'esse cantinho do Occidente gira sobre o facto das primeiras navegações; e para essas, concorreu sobre tudo a communidade israelita que, de tempos immemoriaes, accumulou na Peninsula toda a sciencia e artes trazidas pelos Arabes á Hespanha. (*)

Se as circumstancias historicas da nossa moderna existencia, fizeram de nós um povo de vendilhões egoistas e usurarios (como é fama), pode-se tambem sustentar, sem termos de subir á mais alta antiguidade, que durante bastante seculos fomos nós quem creou condições de progresso e desenvolvimento á peninsula occidental que se debatia nas sangrentas luctas intestinas dos tempos feudaes. Como negociantes, vendemos desde a vil conta de louça até ao escravo com que regalavamos os khalifas; como industriaes, fomos os mais afamados fabricantes de damascos e sedas preciosas, dos celebres marroquins de Cordova, e da bem conceituada cutelaria de Toledo; nas artes e nas sciencias, distinguimo'-nos como alchimistas, medicos, viajantes, astrologos, etc.

*) Esta these está defendida no livro Portugal no seculo xvi esu. into pelo auctor do presente opusculo e proximo de ser dado á publicidade. 
Abrahão Ben Ezra, e Ben David, dão ainda hoje na Historia medida e nome ao que fomos e ao que representámos no desenvolvimento e progresso da humanidade.

Nas perseguições do seculo xv e xvr, melhor se nos accentua a importancia, - sendo para notar que as medidas de perseguição, á nossa raça, affectavam de tal forma Portugal que immediatamente eram revogadas, e a definitiva guerra d'exterminio em tempos de D. João III, foi seguida da quéda immediata da nação!

Em côrtes de 1490, e mais legislação coeva, accentua-se a maxima tolerancia para com a communidade israelita. Após a matança dos Christãos-novos, veiu o arrependimento, a consciencia mesmo dos prejuizos, manifestada pelas cartus régias de protecção de 1509 e 1512. O proprio D. João III, apesar do seu fanatismo, intolerancia e mesmo odio aos Judeus, salva as finanças pelo proteccionismo á judiaria nos privilegios e garantias que lhes foram dadas desde 1522 até 1524.

E' certo que ainda se não fez luz sobre a importancia da raça hebréa na historia das grandezas de Portugal.

Desculpa, amigo, se a exaltação de espirito em que me tenho achado, me obriga a estas digressões. Prometto-te não voltar mais ao assumpto nas cartas que a esta se forem seguindo. O classicismo moderno obriga-nos a longos devaneios antes de entrarmos em qualquer assumpto. Desculpa-me, pois; e crê que me resinto da influencia de meio, e talvez da paixão que em todos os momentos da vida me embarga o coração, pelo anathema injusto que pesa sobre os da minha raça, aliás, raça de heroes!

Eunquanto me deixava possuir por este tumultuar de pensamentos, veiu a manhã com todo o seu cortejo de sorrisos e alegrias, despertar-me das lugubres cogitações por que me deixára absorver.

A insomnia da noite, a realidade da miseria em que afinal me achava, o perpassar de idéas tumultuosas pelo meu exaltado espirito, a consideração das apparencias que a sociedade ambiente me obrigava a sustentar, por manter os principios de dignidade junto ás minhas relaçõ̃es,- tudo isto pesava sobre mim, e me determinou a uma resolução definitiva.

Legalisei os meus papeis, tirei o indispensavel passaporte, e resolvi-me a embarcar. 
Para onde ia? a que me destinava? Não t'o posso dizer. Sei apenas que, n'um momento de desvario, percorri a ultima columna de um jornal qualquer, á busca do primeiro paquete a sahir.

Estavamos a 3 de Junho: no dia 5 partia o La Plata para os portos d'Africa Occidental. Realisei todas as economias que me foi possivel, fechei as mallas, e, depois de tirado o competente passaporte, embarquei. Ia, finalmente, dizer adeus, talvez para sempre, a Lisboa que me fôra berço e mãe.

Não sei que senti, ao vêr afastarem-se cada vez mais as casas, logares, palacios, torres... Sei que me lembrei das palavras de um historiador antigo, que, referindo-se ás margens do Tejo lhe chama com profundo sentimento - Praya de lagrimas para os que vão \& terra de prazer aos q̃ vem. (*)

A verdade da primeira parte do enunciado, já eu a senti. Oxalá possa ainda abraçar-te, para te dizer se a segunda parte tambem é verdadeira!

Não te importunarei com a descripção da viagem que foi das melhores de que tenho memoria n'estas travessias.

$\mathrm{O}$ accentuado caracteristico dos catraeiros ilhavos da $\mathrm{Ma}$. deira; a triste e desoladora feição das rochas de Cabo Verde contrastando com os lindos ramalhetes de verdura, que se chamam S. Thomé e Principe; a profunda impressão simultanea de prazer e desprazer, em vista da variedade de typos, usos e costumes, observados nas poucas horas que permanecemos no Ambriz; a mais exquisita sensação da minha vida, ao chegar a Loanda, que então julguei o telmo da minha viagem !...-tudo isto occuparia folhas e folhas que, embora te agradassem, pouco aproveitariam aos teus estudos de litteratura e geographia.

Eis-me, finalmente, na capital de Angola, firme e resoluto no empenho de te satisfazer o pedido que me derigiste na noite memoravel de que te acabo de falar.

Embora não deseje alongar-me em considerandos, por ter muito que te contal ainda n'esta, permitte que te confesse a minha incompetencia para satisfazer na integra o teu desejo. As notas que te envio, e as que se seguirem nas successivas correspondencias, são mal alinhados conceitos por onde tu, com os teus processos e methodos rigorosamente scientificos, poderás deduzir generalidades e organisar grupos de conhecimentos. Por mim, a insufficiencia propria, e a preoccupação do estomago, não me permittem mais do que descrever-te os

(*) Mariz. Dialogos de vária historia. IV-Cap. XIII. 
costumes taes quaes são, e pela ordem por que os fôr presenciando.

Antes de tudo, preciso falar-te da minha chegada a S. Paulo de Loanda.

Ao fim de dezoito horas (tantas levou o vapor de S. Thomé á capital d'Angola), durante as quaes avistámos toninhas, jamantas, tubarões e algumas baleias, démos fundo em frente do fortim de S. Pedro.

Depois do desembarque achei-me em terra, nas condições mais extraordinarias da vida! Mal provido de dinheiro, com o accrescimo de não entender a lingua do paiz (*) e de não conhecer usos e costumes, nem ter um europeu que n'elles me guiasse.

Era manbã: estavamos a 28 de Junho do corrente anno.

Isto de chegar a paiz extranho, despido de protecções e amigos, constitue uma das melhores condições para penetrar no amago do viver intimo do povo.

De um lado me diziam:

- U'andala mona'ngamba? ("Quer carregador?")

Do outro me tornavam:

- Iza'no, 'ngana iáme! ("Venha commigo, senhor»).

Bem diziam elles, peor os entendia eu.

Alguns querem fazer vezes de cicerini: são interpretes safados, que mal interpretam nossa vontade, interpretando maravilhosamente a nossa bolsa.

Infelizmente eu estava nas condições do proloquio portuguez:- -toca d'onde não sáe coelho!

Logo que desembarquei, a minha attenção dirigiu-se para um edificio espaçoso, pintado de amarello que me ficava á direita:

Era o mercado.

Approximei-me e entrei!

Então pasmei do espectaculo que se me desdobrou deante dos olbos.

A um lado a secção da fuba, de outro a mandioca e a ginguba, aqui o peise salgado em malas de Mossamedes, mais além os pannos, á direita os lenços, n outra parte us esteiras, por aqui as fructas (mangue, banana, cajú e maracujá), por aili as abrboras da terra (grandes, immensas, monstruo. sas), e por toda a parte... que pensas, amigo? que julgas tu

(*) O n’undo. Vid. o que sukre tal as umpto fica escripto no opusculo a que puzéxos por título Linguas d'Africa (já incluido na collecção da Bibliotheca do Povo e das Escholas). 
que por todos os lados eu via, juntamente com o que acabo de te descrever?

Os melbores acepipes da gente do paiz : colla, gengibre, e... ratos, a cinco e cinco, assados com pêlo e tudo, e enfiados pela barriga em caniços adequados!

Antes de seguir adeante na descripção, deixa que te explique como alli se negoceia.

Estavam todas sentadas no meio do chão, as mulheres, que são as que em Loanda fazem o negocio da praça. Como o interior do edificio é exposto ao tempo, ellas usam de uns immensos chapéos ad-hoc, cujas abas são de taes dimensões, que recordam a roda de um cario, isto para não exaggerar no que te escrevo. O fato tambem é extraordinario, mormente para quem, como eu, taes usos não conhecia. Enrolam-se estas mulheres de Loanda em pannos (meléle) de maclusso, tafaxis, zuarte e musselina (nomes estes por que designam os nossos riscados e chitas).

Sentam-se no mercado, no meio do chão, unindo quasi os joelhos ao rosto; o chapéo cobre-lhes as costas e o corpo todo; e, defronte, põem as quindas do genero que vendem.

Além dos europeus que habitualmente frequentam o mercado (ca'ngundo, como lhes chamam por desprêzo), distinguem elles os extrangeiros com a maxima facilidade.

Foi assim que, á minha passagem no interior do mercado, me vi interpellado por numerosas d'aquellas quitandeiras, que, embora a maior parte saibam falar portuguez, me saudavam e interrompiam a cada momento:

- Ai « eh! n'gana iame! ("Ah! Ah! Ah! meu senbor!»)

- Tambula fuba! ("Tome fuba!")

- Iza'no, jungo! ("Venha cá, meu querido branco!")

Não obstante a preoccupação de espirito pelo estado dos meus negocios, tive curiosidade de saber o uso e preço da tal colla, da gengibre e... dos ratos assados!

Perguntei casualmente a uma das quitandeiras o preço dos bixos. Respondeu-me, ao mesmo tempo que me offerecia meia duzia de enfiadas para que eu escolhesse:

-Bend, moari! ("15 réis, senhor" ")

Calculas bem que fiquei grego com a resposta, tanto quanto tu o estarás, emquanto eu te nầo explicar o systema monetario do paiz.

Curvei-me perante a minba ignorancia, e nada escolbi, porque não precisava mesmo dos taes ratos que me causavam apenas nauseas; nem ao nenos consegui entender qual era 0 preço. 
Mais adeante perguntei a uma jutra mulher o preço da colla, que é um fructo amargoso de um arbusto do paiz.

Ella, tomando tres dos taes pomos côr-de-rosa, àisse-me o preço:

- Itato, m'cuta, 'ngana! (“Por tres, 30 réis, senhor!”)

Calculas, amigo, que d'esta vez mais grego fiquei. Não queria, porém, entregar-me nas mãos de um interprete ou languestér, como por aqui se lhe chama.

Prosegui no meu processo, com o intuito de, á custa da minha experiencia, apprender a distinguir ao menos o custo dos objectos, na lingua do paiz!

Vi uma rendilhona de roupa. Aprecei-lhe um par de calças e uma blusa que levava, tudo de chita.

Respondeu-me:

- Macunhi 'tato, miteuâna ni bend! ( 1\$035 réis fortes»).

Cahi das nuvens! Era impossivel por mim só decifrar uma tal linguagem! Recorri ao vizinho mais proximo! Perguntei a um rapazola tambem preto, como todos os filhos do paiz, quanto era afiual o valor do fato, já que na linguagem da quitandeira eu não podia interpretar.

Elle que queria assumir certos ares de pessoa distincta, posto que estivesse descalço, envolvidas as pernas n'um panno sujo de riscado azul e branco, e nú da cintura para cima, respondeu-me em tom muito circumspecto:

- 'Sa mulér diga qu'o melél (panno) custa $1 \$ 725$ réis. (*)

Agradeci-lhe, sorri-me, e retirei-me do mercado sem mais querer saber dos preços, da colla nem da gengibre.

Nào posso n'esta carta referir-te todas as formas por que cheguei a decifrar o enigma do dinheiro na linguagem do paiz.

Agora que já são passados dias depois que aportei a Angola, e que a prática e tambem a necessidade me obrigaram a estudar o assumpto, mais me agradecerás que te explique as conclusões a que cheguei, pondo-te em estado de conbeceres o diuheiro cá da terra, sem teres de te dar aos trabalhos que por mim passaram para o conseguir.

En Angola adopta-se ainda, á hora que esta te escrevo, moeda forte e fraca.

Ha uma moeda de cobre a que chamam macuta, cujo valor é de 30 réis fortes ou meio-tostão fraco, e outra tambem de cobre chamada bend, equivalente a 15 réis fortes ou 25 réis

(*) Imitação òa lingusgem dos indigenss, quando preterdem falar em portuzuez. 
fracos. Logo, cada duas macutas, contam-n'as os indigenas por um tostâo, que para os europeus equivale apenas a 60 réis. (*)

Por conseguinte dez macutas (cunhi a mucuta) são cinco tostões fracos, ou seja 300 réis.

Agora, para melhor interpretares a numeração e contabilidade de Angola, consente que te importune com mais alguns esclarecimentos.

A contagem é do modo seguinte:
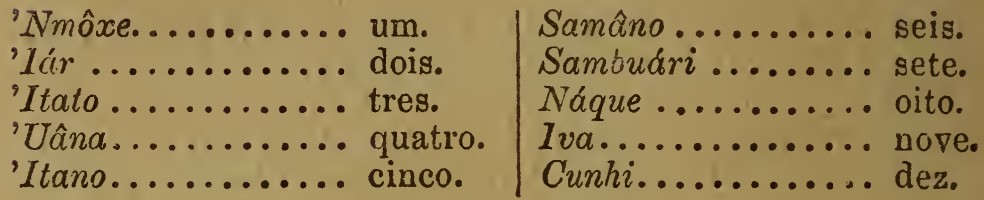

Sendo cada cunhi dez, segue-se que para dizerem 20,30,

(*) Angola principiou a ter moeda sua desde 1762 . Foi no reinado de $\mathbf{D}$. José que, pela primeira vez se cunbaram, na Casa da Moeda de Lisboa, uus dinheiros de prata, cuja valia era de doze macutas, 600 réis fracos ou fôssem 360 réis d nossa moeda sctual.

Na Memoria das moedas correntes em Portugal desde o tempo dos romanos até o anno de 1856, por Manuel Bernardo Lopes Fernandes (Cf. Mlemorias da Acarlemia Real das Sciencias de Lisboa-Nuva Serie, 2. ${ }^{a}$ classe, T. 2. ${ }^{\circ}$ Parte $\left.1 .{ }^{2}\right)$ colbem-se curiosas e muito interessantes noticias a I espeito das moedas correntes em Angola.

- A macuta (diz a Memoria citada) era moeda de conta, ou forma de contar «de que usavam os n gros em alguns sitios da Costa da Africa, e particularrmente em Angola. Estabelecido o numero d'estas moedas que pretendiam e por um escravn, avaliavam tambem em macutas os differentes obje tos que edeviam dar em troca, e por esta forma faziam todas as suas transarçōes. Pa. erece que por este motivo o sr. D Joné I mandou lavrar as moedas de prata * de cobre, com o nome de Macutas, e com o valor de meio tostão, para fi. carem representando, como mocdas effectivas, as formas por que alli ee cuu. ctava.s

As rrimeiras moedas que se cunbaram eram de prata, ccm a dвəižaçảo e valor de doze, dez, oilo, seis, quatro e duas macutas.

Tinham um escudo de armas, rodeado pela saguinte legenda:

Josephus i. D. G. Rex. P. et D. Guineas

No reverso lia-se em volta:

Africa Portugueza. 1763

E no campo havia dois ramos de louro, teudo no centro

MACUTAS 12

ou o numero que representava u valor. 
40 , etc., repetem o numero de macunhi (*) duas, tres, quatro vezes, etc. Assim macunhi 'ar vale 20, macunhi sambuári 70 , e assim successivamente. Quando estes numeraes se referem á unidade macuta, cada dez valem cinco tostões, e, antes dos dez, precedem o numeral do prefixo mite, dizendo mit'iar (2 macutas), mite'tato (3), mite' $i$ âna (4), etc. Chegando a 7, 8 e 9, dizem, porém, sambuári'a macuta, naqu'a macuta, iv'á macuta.

Depois de assim te ter informado n'esta materià, prosigo na minha narrativa que, por primeira, já vae longa.

Abandonando o mercado, cujo aspecto geral me desagradára, pensei em satisfazer as necessidades da minha alimentação.

Fui, pois, seguindo ao acaso pelas ruas da cidade baiza, sem bem saber aonde ne dirigia.

Várias vezes parei a contemplar um espectaculo para mim inteiramente novo. Eram os grandes senhores da terra que, findos os seus negocios, se dirigiam em machillas, carregados aos hombros de dois pretos, com destino ás boas proprieda. des da cidade alta ou aos muceques (especie de chalets de recreio, que ficam situados nos arredores da cidade). Seguindo-os casualmente, achei-me n'um bairro vasado em moldes diversos de tudo que até então eu tinha visto. Era a Ingombota (**), logar dos pretos: um montão de mal aliuhadas, mal

A moeda de prata desapparecia facilmente da circulação, porque o indi. gena se apoderava d'ella para enfeite.

De egual teor ae cunbaram em cobre com a designaçåo e valor de Uma macuta e meia macuta. Esta ultima chamava-se officialmente Equipaga e ainda em 1876 e 1877 a vimos correr no interior da colonia, com o nome de 'Ipaca e tambem bend, por que era mais coubecida.

O Pano era uma moeda do mesmo tempo. Valia 5 réis. Desappareceu ba muito da circulação, e ainda d'ella ouvimos falar com desprêzo, dando-lhe o indigena o nome pejorativo de mulemúngo.

Algumas d'estas incedas que, por muito tempo se cuubaram em Lisboa, passaram em 1814 a ser lavradas no Brazil d'onde eram remettidas para Angola. As de 12 macutas de prata, e as de cobre de 1 macuta e meia macuta, foram novamente cunbadas no reinado de $\mathrm{D}$. Maria $I$, e, por uma medida official, passaram a receber uma especie de carimbo que lhes dava o dôbro do valor. Foi uma forma artificial para crescer o numerario, emquanto se näo introduziu na colonia o papel-moeda, emittido pela extincta Delegação da Junta da Fazenda, e pela Succursal do Banco Nacicnal Ultramarino, em Loanda.

Em tempos de D. Joăo VI foi ainda reforçada a cunhagem das macutas, que tomou o seu maior incremento nos reinados da rainha $D$. Maria II e D. Pedro V.

Para estudar a cunbagem de moeda para o reino e para o ultramar, ef. Aragão-Numismatica.

(*) Ma é um prefixo 'nbundo que serve para pluralisar os nomes.

(**) Cf. Vol. CLXIV da Biblintheca do I ovo e das Escholas. 
construidas, sordidas e immundas cobatas, sem ar, nem luz, nem condições algumas de habitabilidade e limpeza.

A cobata de Angola é o que pode haver de nojento e hediondo. As mais tôscas formas da nossa architectura teern feição demasiado sumptuosa, para que por ellas se possa formar uma pequena idéa da cobata. Quatro balaustradas de bordão enterrado na terra, amarradas umas ás outras com guita do matto, formam uma especie de tôscos tabiques a que elles, depois de tudo coberto de barro amassado em agua, chamam pomposamente - as paredes! Estas, a principio lizas, estalam em milbares de boccados ao tim de poucos dias de sol esbrazeador. O tecto é formado tambem com bordões ou paus estreitos de cajueiro, que depois cobrem de capim!

Uma porta estreita e uma ou duas janellas muito pequenas constituem os unicos ventiladores d'estes coutos da hediondez.

Aqui, amigo, n'este bairro, habita a casta negra.

A praz-me descrever-t'o, porque é muito possivel que não tenha tão cedo occasião de te falar n'elle.

O terreno onde este monte de casaria está assente é muito accidentado. Por aqui e por alli passeiam á solta porcos, gallinhas e gado lanigero. No meio do chão vêem-se esteiras desdobradas, sobre as quaes estão deitados homens, mulberes e creanças, todos a fumar e a beber aguaraente: as mulheres enroladas em pannos, quasi sempre sujos; os homens embrulhados em suas tangas que os cobrem da cintura para baixo; e as creanças de ambos os sexos, até á edade de oito e dez annos, brincando todas nuas por aquelle nojento bairro.

Entrei n'um d'aquelles antros que mais me pareceu ser casa de comida.

Calculas que não havia lista por onde escolher; se tal me conviesse, ter-me-hia dirigido de preferencia á hospedaria do Mangueira ou a outra qualquer das bastantes que ha na cidade baixa.

Mas a verdade é que me cumpria economisar, e mesmo sentia-me possuido do desejo de bem estudar os costurnes genuinos do paiz. Não devia para isso procurar os logares onde a influencia européa já tinha alterado os usos. E' geralmente no seio da miseria que as formas, costumes, lendas e tradiçòes de um povo, persistem, longe de influencias extranhas que as alteram.

Effectivamente, alii comia-se! Era uma loja onde cs carregadores e libertos tomavam as suas refeições. $O$ balcão e as prateleirus eran formados de empellas ou veios da rama da palmeira. Pelo chão havia quindas com tuba, milho, gingu. 
ba torrada e peixe assado, que se vendia a razão de um bend cada posta! Bem deves suppôr que só o aspecto d'isto tudo me tirou o appetite de que me achava possuido.

A casa tinha freguezes!

Uns comiam peixe assado, com farinha-de-pau! Outros serviam-se do bombó ou mandioca assada, com ginguba torrada! Alguns divertiam-se a comer com as mãos uma especie de massa ou gomma consistente e pegajosa, feita de fuba de milho e de mandioca, ao que dão 'o nome de 'nfundgi, e que constitue um prato obrigado da cozinha 'nbunda.

A maior parte, porém, estava á torneira de um barril, matando o bicho, como é habito dizer e fazer.

Virei costas; tornei á cidade baixa, onde entrei n'uma hospedaria aportuguezada, em que fui razoavelmente servido, preferindo pagar mais alguma cousa, a entrar na contingencia de comer farinha e peixe com a mão, tendo talvez de me servir do chapéo como prato, e da esteira como mesa.

Não posso n'esta ser mais extenso. Deixo-te no ponto em que re acho; esperançado em fazer muito, gastar pouco, juntar o mais possivel, afim de poder tornar a ir jogar comtigo alguma partida mais de zadrez no Café-Marticibo.

O Deus de Israel superintenda sempre nos teus negocios, como mereces.

Teu amigo

Ben Zacheu. 


\section{CARTA SEGUNDA}

Calumbo, 7 de Agosto de 1876.

\section{Meu caro:}

Se na carta anterior pouco tive a referir-te relativo ao objecto especial d'estas minhas correspondencias, informo-te de que esta trata exclusivamente de Angola, nas peripecias do seu viver intimo.

O judeu caminha, caminha sempre em cumprimento do anathema lendario; caminha, embora mesmo seus passos assignalem a ruina e a desgraça.

Como vês, esta vae datada de mais longe.

Informações, propostas, conselhos, circumstancias, emfim, cuja enumeração nã̃o vem agora ao caso, determinaram-me a ir para o Cuanza. Resolvi partir tres dias depois d'aquelle em que te escrevi a minha ultima. Até abandonar Loanda, prevês que não voltei mais ao immundo bairro da Ingombota, cujo aspecto me deixara bem mal impressionado.

Aconselhei-me com uns e outros sobre o modo de me fazer. conduzir até ás margens d'aquelle importante rio. Eu podia optar por differentes vias de conducção. Tomar passagem a bordo de um dos vapores de cabotagem da casa Newton Carnigie \& C.a, ou entrar n'uma das lanchas do Pedreira, capitaneadas por habeis cabindas, ou alugar um boi-cavallo, ou mesmo fretar carregadores, e seguir em tipoia ou rede, ás costas dos mesmos, por terra dentro, até chegar ao rio que demandava. Eram estes, porém, meios dispendiosos para ụm homem que se achasse em condições identicas ás minhas. 
Tudo isto rejeitei, optando por dirigir-me até Calumbo, concelho marginal do Cuanıa, a pé, seguido apenas de um carregador que me conduzisse a bagagem.

Tomei a meu serviço um preto, de nome Samba-eb, e condensei a minha pouca bagagem quanto possivel, mandando 0 resto por mar.

Amigo, eis-me prompto para a primeira excur'são ao interior. Samba-eb passou a ser o director prático da viagem. Seguia-lhe os passos, os pareceres e os conselhos.

Partimos para fora ao anoitecer, na direcção da Ingombsta, que por segunda e talvez ultima vez ia avistar, tendo-me prevenido com o indispensavel para viagens como a que resolvera emprehender.

Posso por curiosidade descrever-te o meu rancho d'esta occasião, para fazeres idéa de como as cousas aquui se passam.

Samba-eb comprara-me quatro macutas de peixe sêcco, uma lata de sardinhas de Nantes, uma botija com aguardente e doze rôscas de pão, a 15 réis cada uma. Por sua parte, preve. niu-se com duas macutas de farinha e ginguba, um bęnd de malagueta, e uma bilha... com agra!

O aspecto da Ingombota á hora do escuro, em que a atravessei, era phantastico e mesmo medonho. Parecia uma grande montanha de cinzas apagadas á superficie, mas cuja incandescencia irrompia do interior por aqui $\epsilon$ por alli.

O bairro não é illuminado; as cobatas teem fogueiras dentro toda a noite, e a claridade transparece cá tora, através dos milhares de fendas das paredes.

Quando já proximo a sahir do hediondo bairro que tanto me impressionara, ouço um côro mal entoado, de muitas vozes que me chamaram a attençào. Retrocedi uns passos, na companhia do meu serviçal, €m direcção do som.

N'uma immensa e muito velha cobıta, notei que muitos pretos e pretas, em trajos quasi primitivos, entoavam uma extraordinaria cantiga, assumindo ares profundamente piedosos. A minha curiosidade ficou excitada; lembrei-me da missão que me tinha imposto de te descrever os usos e costumes do paiz, - e, pedindo licença a uns e a outros, nenetrei. Recordaramme então as celebrações dos primitivos Christãos nas catacumbas e antros da velha Europa, no tempo ca perseguição dos primeiros imperadores romanos.

Reffe ti, porém, que taes processos não cram necessarios n'um paiz officialmente christão! Em poucas palavras te refiro o que vi.

Ao fundo da cobat a havia un crucifixo relho e muito sujo, 
sobre uma mesa de mafumeira, que é para Angola madeira mais ordinaria que entre nós o pinbo da terra. Uma lamparina de barro, cheia de azeite de palma, a que un retalho de chi a dobrada de um modo conveniente servia de torcida, constituia a illuminação da imagem.

As paredes eram todas de barre estalado; aos cantos, $\mathrm{cm}$ forma de estante, algumas tábuas continbam garrafas vazias, muringues e panellas. Do tecto, que era de capim, segundo o costume, pendiam, juntamente com ais muitas teias de aranha, umas cordas que sustentavam algumas duzias de maçarocas de milho! No chão havia por aqui e por alli cavacos de lenba esbrazeada, em volta dos quaes se agglomeravam pretos e pretas, que fumavam sofregamente nos seus caracteristicos peixes e tengas (cachimbos) ao mesmo ternpo que entoavam o tal côro desbarmonioso. O povo apinhava-se até fora da porta, levados uns pela curiosidade, outros pela desoçâo!

E' da maior probabilidade que me perguntes o que fazia esta gente. A resposta não demora: cantavara o Evangelho em $n^{\prime} b u n d o$ afim de pedirem chuva para as co'heicas e sementeiras.

A estas preces ad petendam p'uviam chanin. elles: o mucundgi.

Certo do que se tratava, voltei fora, e prosfgui na viagem a que me destinava, sempre guiado pelo meu Sámba-eb.

Abandonámos finalmente a Ingombota, para entrarmos n'um terreno dos que por aqui e por alli permeiam por toda Angola, com os uberrimos torròes. Era um campo arido, diunotono e deserto: um verdadeiro areal sem mais vegetaçào do çue a de algumas caçoneiras e imbondeiros! Nào sabiamos se ávan. çavamos, ou se retrocediamos, porque os pés se nos enterravam no solo, até a altura dos joelhos.

Era noite fechada; ainda não bavia meia bora que eu entrara n'este novo terreno, e já me sentia extenuado e sequioso. Principiei a avaliar a grandeza do pensamento do meu Samba-eb, em carregar agua para a riagem.

$O$ arrependimento da empresa, a que mettêra hombros, depressa se fez sentir. Julgava-me só, n'estes immensos areaes; pensava que eu e o Samba-eb eramos os unicos cntes que haviam emprehendido tal derrota. Todavia, elle bem me desenganava, affirmando-me que, áquella bora, de todos os lados do areal caminhavam bandos de gente que iam, como nós, em direeção ao primeiro povoado-Cavúa-que já estava proximo, no dizer do preto.

Conquanto o não acreditasse, em breve a realidade se me 
mostrou. Passada meia-hora de viagem nas areias, o que me pareceu um seculo, principiei a ouvir unito borborinho, até que nos approximámos do tal logarejo-Cavúa - suspirado oasis d'aquelle maçador Śabsrá.

Abi fizemos Quilombo (isto é, paragem para descançar, co. mer e dormir até ao romper da manhã). De todas as bandas chegavam homens, mulheres e creanças (tudo gente preta), que vinham pernoitar ao sereno. Accendiam fogueiras, desamarravam suas cargas, e entregavam-se, em roda do lune, ao serviço de fumar, beber e comer peixe sêceo assado nas brazas, ou ensopado em agua e malagueta.

Segui-lhes o exemplo, comendo com o meu serviçal do que levavamos, e fumando tambem.

A provisão d'agua já se havia acabado: tive por essa occasiâo de dar um bend a uma mulher pertencente aos dois ou tres fogos que constituem Cavúa, por uma caneca d'agua tirada de uma poça destinada a beberem os bois-cavallos que por alli passam.

$O$ resto da noite foi das mais incommodas de que me lembro na vida. Cada qual desdobrou o seu mosquiteiro, e entrou n'elle, onde dormiu sobre esteiras até ao amanhecer', perfeitamente abrigado de importunos. Eu, porém, que, por ignorancia dos costumes, com tal objecto nâo me tinha prevenido, passei a noite de véla, fumando... e matando os mosquitos que por Angola são ás nuvens, constituindo uma verdadeira praga. Não foi o meu Samba-eb mais feliz do que eu n'este ponto; tambem não poude dormir. Então conversámos.

Como prático, informou-me que de Cavúa para deante teriamos ainda de encontrar Camama, Mateia, e mais alguns insignificantes povoados, antes de chegarmos a Calumbo. Felizmente, porén (dizia-ıne elle no seu portuguez mesclado de n'bundo), teriamos cada vez mais companheiros de viagem, o que me devia consolar.

Effectivamente, seguindo a sentença.latina - sōlatium est miseris socios habere penates - era justo que eu me consolasse de ser acompanhadn para deante por uma fileira, quanto mais comprida melhor, de pretos e pretas que ao menos sem. pre iriam cavaquesudo (embora eu não percebesse uma só palavra do que fôssiu dizendo).

Emquanto assim commentavamos ao mesmo tempo que matavamos os mosquitos que de mais em mais nos perseguiam, a almejada aurora rompeu alegre e sorridente.

Cada qual se ergueu, as cargas acavallaram-se nas respectivas costas, e a caravana (de Cavúa em deante, esta via. 
gem torna-se caravana!) seguiu á busea de Camama, que fica proximo!

Não preciso falar-te do resto da viagem, eivada de muitas peripecias, que na realidade não interessam em nada os teus estudos.

Chegámos finalmente a Calumbo (concelho que defronta com o Cuanza).

Aqui pelo interior não succede como nas cidades, em que o extrangeiro aluga um quarto, ou se hospeda em qualquer hotel.

Valem-nos os conhecimentos, ou o direito de hospitalidade consignado pelos usos e costumes do paiz.

A' ininha chegada, Justino, um branco, o unico da localidade,-Q ituto (como vulgarmente lhe chamam), - velho militar reformado, veiu ao meu encontro, e levou-me com o meu creado para sua casa, que era uma loja de molhados.

As lojas do interior sào extraordinarios especimens do commercio! N'uma prateleira ha chitas, ao lado uma manta de toucinho, n'outra uma caixa com tampa de vidro expondo relogios de prata e anneis de ouro; junto com chapéos de palha da terra, vêem-se chapéos-de-côco, finos, europeus. A um canto ha saccos cheios de cabullo (especie de feijão indigena); n'outro, muitas gangas e panellas de barro sordidas e nojen. tas, cheias de azeite de palma. Além uma pipa com aguardente de canna do Bom-Jesus. No balcão, geralmente feito de empellas e esteiras, ha uma travessa cheia de peixe frito em azeite de ginguba, e uma gamella de páu com farinha de mandioca, e outra com fuba de milho. No meio do chão vêemse umas esteiras extendidas, onde uma ou duas pretas, de cócoras ou deitadas, fumam nos seus cachimbos, emquantd um negralhão toca no seu humbo, especie de guitarra de uma só corda a que o corpo nu do artista serve de caixa sonora!

Imagina qual seria a impressão que recebi deante d'este grotesco espectaculo, para mim bem pouco edificante!

Felizmente a lhaneza e amabilidade de tratamento do velho Quituto, contrabalançou toda a minha má disposição para me adiptar aos extravagantes usos e costumes que principiavam a desenrolar-se deante de meus olhos.

A lei sociologica - que o homem se resente do meio em que vive - adquiriu para mim a firmeza de um dogma. Durante os poucos dias que tenho vivido em Calumbr, na companhia do Quituto, assistindo ao negocio do seu pouco custoso estabelecimento, tudo me tem feito sonhar delicias!

Quão feliz seria, tenho eu pensado, se por esse interior con. 
seguisse montar uma casa de negocio como a de Quitutoo pae dos brancos!

Tanto tenho acariciado esta idéa, que já penso em tornal-a realidade.

Aqui, onde ninguem ha que me conhecesse em Portugal, posso montar uma casinha de negocio que troque com os negros farinha por cêra, missanga por azeite de palma e de ginguba, e chitas por borracha. A profissão é condigna de um judeu nos unodernos tempos!

Posso com isto fazer muito.

Sabe que alguns dos maiores negociantes d'aqui de Angola, principiarain o seu negocio no tempo em que, degredados, ainda uão tinham concluido o tempo da expiação, pedindo emprestadas algumas macutas com que compravam peixe para fritar e vender aos anangama, em Loanda! O negocio rendia-lhes: as macutas tornaram se tostões, e estes fizeramse libras, as quaes depois adquiriram as proporções de contos! Eil-os agora tornados grandes senhores do paiz!

Amigo, quem dera que o Deus de Israel secundasse os meus bons intuitos, para que, pelos meus esforços e trabalhos, podesse em breve regressar a Portugal, em estado de reapparecer no meio da sociedade que me desamparou á hora do meu desastre financeiro!

Teu amigo

Ben Zacheu 


\section{CARTA TERCEIRA}

Maculumby, 6 de Novernbro de 1876.

Amigo:

Terás extranhado tanta demora, sem noticias minhas. Nã๊ é que me tenha esquecido de ti: foi, por assim dizer, o recuar do tigre para formar salto maior. Não desejava eu escreverte todos os mez s, para te occupar de bagatelas pessoaes que em nada te elucid issem. 'ara te poder narrar com fidelidade as cousas d'aqui, foi preciso que eu tivesse tempo para me habilitar a comprehendel-as. A preoccupação individual com os meus negocios tambem me inhibia de prestar a devida attenção ao que ia vendo pelos territorios que atruvessava. Bons mezes vào já passados, depois da minha ultima. Os negocios entraram em bom cuminho, sum yue eu deva n'esta occupar-te sobre o modo por que consegui arranjar as finanȩas.

Actualmente vivo em Maculumby, onde puz uma casa de negocio, contorme eram meus planos: A sorte tem me bafejado; o crédito resolveu as difficuldades, e diligenceio que a minha honradez me permitta ser digno das mercês que de Ado. nai tenho recebido.

Reatando os acontecimentos que mais te interessam, do ponto em que na carta anterior os deixei, dir-te-hei que resolvi definitivamente abandonar Calumbo, e seguir pela margem direita do Cuanza acima, acompanbado apenas do meu Samba eb. Viagem incómmoda, sem duvida, e brigad $a$ a mau passadio! Hoje, com a prática que d'estas cousas vou tendo, 
reconheço que esta é a inais apropriada forma de viajar pelo interior, no intuito de estudar usos, costumes e lingua.

Durante uns quinze dias de viagem vagarosa e descançada, sem auxilio de tipoia, maxilia, nem comitiva, mereci attenção, e causci o espanto de homens, mulheres e creanças, algumas das quaes fugiam adeante de mim, tomando-me por ave$j a ̃ o, c a z$ r.bi, etc., visto eu ir apenas com um serviçal, o que é contrario ao uso dos europeus que por aqui transitam sempre armados, e com um grande séquito de creados e carrega. dores.

Entendi, porém, que, para os indigenas confiarem em mim, necessario era que eu, extrangeiro, confiasse n'elles. Segui, pois, viagem, convivendo e tratando lhanamente com todos que se me acercavam, tomando sem escrupulo algum maluvo (vinho de palmeira) en meias cabaças, todas as vezes que por obsequio m'o offereciam, extendendo a mão a uns e a ou. tros, e dando benção ás creanças que se me deparavam, segundo o estylo do paiz.

Por differentes vezes encontrei sobas, potentados do logar, acompanbados dos seus macota (especie de ministros), dos quaes um traz um páu com dois ou tres castioes (em garfo ou em tridente), outro a quibaca ou banco onde o soba se assenta para dar justiça, e outro o bassá ou sceptro, designativo de auctoridade. Andam quasi sempre acompanhados de seus filhos, muleques, acage (concubinas), etc.

Sempre passei perfeitamente, sendo recebido em todas as cobatas a que me dirigia, com as regalias da proverbial hos. pitalidade de Angola.

Devo-te confessar que a attitude aggressiva dos brancos, aqui, como na America, é a causa determinante das represalias do indigena.

Já no pouco tempo em que aqui resido, tenho ido aos seriões do Libollo e da Quissama,-e nunca os filbos d'aquellas regiões me atacaram, pela razão de me não tomarem como inimigo que lhes ia roubar as terras, mas como um bom enviado de n'gana Zambi ("o senhor Deus»).

Foi durante uma d'estas viajatas, rio acima, pela margem portugueza, que pela primeira vez assisti ao Culemba, ao Itam. bi, ao Cubeléla e ao Quizomba, cerimonias indigenas de casamento, enterro e dansas.

Cheguei, finalmente, a Maculumby, divisão do concelho de Massangano, depois de ter soffrido todas as contingencias de quem anda por estas paragens, como a perseguição dos mosquitos, a passagem a vau dos muige, que são ribeirinhas pe. 
rigosas, usual residencia do n'gandu ou jacaré (como aqui vulgarmente lhe chamamos), $\mathrm{e}$ a excursão ás vezes inesperada da quingoenha, quimalanca, e outros animalejos do genero felis.

-Aqui montei uma lojinha pobre e mal fornecida, como as muitas que no interior se acham espalhadas por todo o matto, pelo que se usa chamar-lhes lojas do matto ou aviados.

Os principaes generos de negocio são aguardente, polvora, armas lazarinas, machetes de commercio, chitas, algodões, zuartes, lenços, missanga, maclusso e tafaxis, de que já em uma carta anterior te falei. Costuma tambem haver n'estas casas feijão, milho, fuba, e peixe sêcco de Mossamedes,-_comquanto por todo o interiur, nos rios e lagôas, nunca falte abundancia de um peixe d'agua-dôce pequeno e saboroso, a que chamam cacusso.

Maculumby acha-se situado um pouco abaixo do rio Lucála, confluente do Cuanza. Sua população é toda de côr preta. Tementes e supersticiosos, arreceiam-se de feitiços, e juram por n'gana Zambi, o poder supremo.

Trabalham e trabalham muito. Suas principaes occupações consistem na apanha do denden (fructo da palmeira), no fabrico do magi ma'n dende (azeite de palma para neg cio e tempêro domestico), e manipulação de fuba e tabaco. (*)

Teem esteiras diversas a que chamam gand, machissa e luandu, e fabricam para o commercio saccos de liconde e mateba (especie de esparto indigena).

Afóra isto, pescam, caçam, ccnstróem suas cobatas, fazem muros ou sébes e cercados para os porcos, cultivam bastante, e ainda lhes sobeja actividade para se entregarem á orgia, embriagando-se, homens, mulheres e creanças, para perderem as noites no Quizomba e Cubeléla, dansas voluptuosas de que te farei descripção especial, n'uma das minhas proximas correspondencias.

Tal diligencia em população tão rude (reconhecerás, amigo) bem mostra quão aproveitaveis virão a ser ao commercio e á industria colonial os filhos do Cuanza, quando a eschola aqui tiver dissipado as trevas da ignorancia, e a locomotiva soltar o silvo da civilisação. (**)

Até lá, doloroso se torna para os corações sensiveis viver no meio d'estas immensas florestas de palmas e coqueiros, for-

(*) Cf. Vol CLXIV da Bibliotheca do Povo e das E scolas, pa g. 51.

$(* \star)$ Além do caminho-de-ferro de Loanda a Ambaca, atravessando Angola em diagonal, existe já um immenso projecto para communicar Africa Occidental com Moçambique, por via de uma ligação ferro-viaria entre o Cuanza o Zambeze. 
çados a sanccionar com a presença actos de verdadeira rusticidade e ás vezes cannibalismo, a que as nossas leis, por mais liberaes e peremptorias que as desejemos, nem sempre podem pôr côbro.

Durante a minha relativamente curta demora em Maculumby, bastantes vezes de mim se acercam alguns quissamas nús, untados de azeite de palma, conforme o uso do sertão a que pertencem.

Veem de longe, de bem longe, do sertão onde nem nós nem outra qualquer nação européa exerce a sua acção civilisadora. Trazem suas mulheres, seus filhos, irmãos, creados, e tambem seus escravos, porque, onde a lei européa não pode chegar, o preto exerce despotismo sobre as castas que lhe são inferiores.

Approximam-se de mim; nas mais das vezes, apresentamme algum preto trémulo, choroso, magro, e quasi sempre coberto de feridas provenientes de maus tratos recebidos, e perguntam-me, com a voz natural e franca de quem trata sobre materia corrente:

- Uandala ié co sumbo bica? ("Quer comprar um escravo?")

- Guáme iáme ("Não quero"): é a minha resposta positiva e indignada, mas habitual.

Os Quissamas submettidos, depois das minhas palavras, usam chorar ainda mais.

A offerta, o desgôsto dos escravos por occasião da recusa, tudo isto emfim me chamou a attenção para factos d'esta natureza.

Alguns individuos d'aqui da localidade explicaram-me quanto humano era tornar conta dos pseudo-escravos, e pagar aos quissamas o preço exigido, para, a titulo de resgate, dar a liberdade a estes desgraçados que, a nào serem vendidos, são mortos no sertão. (*)

Poucos dias depois de eu estar fixo em Maculumby, foi a minha attenção despertada n'uma noite pelo toque repetido de puïta, especie de tambor indigena. Ergui-me da esteira em que dormia (nem aqui no matto os calores permittem outra cama), sahi de debaixo do meu mosquiteiro de xila, e che. guei fora da porta, a affrontar o incómmodo dos mosquitos e

(*) O espirito da nossa lei, auctorisando os resgates no sertão, é opporse ao despotismo e á violencia do homem sobre o homem. A's vezes a lei é sophisnada no interior, poı muitos brancos, mas é esse um abuso que a lẹi não sancciona, e pelo qual a nação portuguez não deve ter responsabilidade, segundo nos parece. 
o risco da quingoenha, só para saber o motivo da muslea phantastica que em nada semelhava o toque do Quizomba.

A superficie do Cuanza, illuminada pelas togueiras ateadas na margem opposta, parecia um immenso lençol de togo; e ao brilho das mesmas vi bastante gente, cujas vozes, trazidas até mim, indicavam que alli se chorava em altos brados, segundo o estylo africano, pela morte de um individuo.

- Enterro! calculei eu. E retirei-me.

Escusado é dizer-te que o meu Samba-eb, dorminhoco como todos os habitantes de entre-tropicos, resonava estrondosamente, sem ter dado por cousa alguma do que lá fora, na margem opposta do rio, se passava.

De manhã, os vizinhos, ainda a limparem os dentes com um pruzinho (como usam), disseram-me, muito preoccupados, como por um grande acontecimento, que já o crocodilo houvera traqado um escravo, em castigo de um grande quituche (delicto).

- Ueb? ("Onde?»)

- Mu'Issama, 'ngana! ("Na Quissama, senhor!»)

- Quizúla cúsh? ("Quando?")

- Mazá, m’hossuco! ("Esta noite!»).

Tal cúmulo indignou-me; todavia, eu não achava remedio contra tanto mal, a wão ser a luz da civilisação que, só através do tempo, poderá penetrar nos sertòes de Angola. Por isto, a lei já faz muito (com quanto do seu espirito alguns brancos no interior abusem), permittindo o resgate, por cujo meio se evitam numerosas victimas. O escravo quissama, libollo ou bailundo, commettendo quituche, isto é, delinquindo, faltando ás leis consuetudinarias do sertão onde regide. ou desobedecendo ao seu senhor, é julgado, e, no caso de criminoso, tem de ser vendido. Se não acha comprador, paga com a vida o seu delicto.

A curiosidade, mãe nata de todos os progressos da humanidade, convidou-me a entrar n'uma canôa de mafumeira, como são todas por aqui, e a atravessar ou tabucar (como se diz, aportuguezando o vocabulo n'bunio (*) para a Quissama. Dirigi-me aos dominios do soba Quinebuto (sempre em companhia do meu Samba-eb), os quaes ficam por terra dentro, em linha fronteira a Maculumby.

Alli fui satisfatoriamente recebido como todos que se fazem acompanbar de valiosos presentes. N'estas reciprocas provas de affecto, devo confessar-te que ficamos sempre logrados,

(x) Cu tabuca. 
mormente ao trocar com pequenos potentados, especie de exploradores do povo que em Africa, como por toda a parte nunca faltam. Assim, em trôco de alguns mactes de missanga para as mocambas e acage do soba, um barril com duas libras de polvora, uma espingarda lazarina, uma peça de mussclina e seis garrafas de aguardente, recebi... calculas que terei eu recebido? Seis gallinhas, um prato de cera suja, um quito (*) de oleo de palma, e... quatro cannas saccharinas (como especialidade, por se não cultivarem na região).

Feitas, pois, estas ruinosas trocas, estabeleci com o soba e seu povo relações da mais cordial amizade.

Só então me foi possivel saber, de fonte certa, como as cou. sas pơr alli se passam.

Por differentes rezes tenho já assistido ao julgamento no sertão. O réo é accusado de um qualquer quituche, como o de ter roubado uma terra de mandioca, uma gôtta de azeite de palma, ou uma carga de polvora. A's vezes o seu crime é ser feiticeiro, segundo a superstição local, ou manter relações amorosas com uma qualquer mulber, sem haver satisfeito o n'lemba (imposto de mancebia pago aos paes).

O julgamento, que é sempre feito ao ar livre, corre com todas as formas de superstição, na presença do soba e dos quibanda (que sâo cirurgiõeś feiticeiros), povo e mais interessados. A causa é finalmente classificada quituche ou feitiço.

No primeiro caso, o soba ordena os exorcismos que se executam de noite, e, no segundo, condemna. Ou o criminoso so. fre castigos corporaes, flagellaçòes, etc.; ou é sentenciado a ser vendido por certo preço. E no caso de não achar comprador, conduzem-n'o á beira do Cuanza, onde o precipitam com uma pedra amarrada, afim de com seu corpo immundo aplacar as choleras do n'gandu (crocodilo).

A festa nocturna que tanto me sobresaltára, era isto: - un criminoso que, não tendo achado comprador, fôra precipitado ao Cuanza.

Além do que eu proprio ia comprebendendo, explicavam'o, com clareza, laconismo e sobretudo naturalidade, o meu Samba-eb, assumindo ares de quem se orgulhava dos usos dos da sua raça!

Devo aqui expressar-te uma verdade, ainda que nos pese confessal-a. A nossa acçào civilisadora em Angola tem sido inefficaz, nem mesmo equivalente á exercida pelas outras nações européas, sobre as suas colonias, nossas circumviziuhas.

(*) Especie de pote de barro. 
A vida e actividade de Serra Leoa, Monrovia e Gabão ao Norte, e a de Cape Town (na Colonia do Cabo) ao Sul, é muito superior á de Loanda, Benguella e Mossamedes. Curo d'isto com tanta proficiencia, pelas informações directas que sempre (como tu muito bem sabes) d'alli tenho recebido, desde os antigos tempos em que eu negociava forte com aquellas praças.

Todavia somos nós a naçầo que, de mais longa data, possue grandes tratos de terreno em Africa! Isto é devido, com amargor o digo, á incuria e inhabilidade nossa, como potencia colonial.

Quem se informar da historia de Angola, nas suas verdadeiras fontes, como são os relatorios officiaes, as relações de missionarios, os manuscriptos de Domingos de Abreu de Brito em 1592 (hoje existentes na Bibliotheca Nacional de Lisboa), os trabalhos de Antonio de Oliveira Cadonega e outros, saberá que a Quissama, como os Dembes, Cassange, Lunda e outros sertões, já nos estiveram avassallados por muitos annos. (*) Ainda em Muxima (Coração), e outros pontos do interior, se mostram vestigios do nosso assombroso poderio, em grossos e desmoronados baluartes por umas e outras partes espalhados, e lá no fundo da Quissama (dizem-n'o aqui os ve. lhos do Cuanza, por o terem ouvido da bôcca de seus paes) existem, proximo das sempre afamadas minas de sal, os restos de um antigo estabelecimento de monges portuguezes.

Esse velho poderio, esses assombrosos esforços que fizemos para dilatar a fé, o imperio, na phrase do grande épico portuguez, succumbiram ante o descurar das grandiosas tradições cavalleirescas que nos deram animo para tantas e tão arrojudas empresas.

Vamos actualmente assistindo á nossa exautoração de potencia colonial, perante o mundo boquiaberto. No que nos resta, governamos nominalmente, ainda que pese dizel-o, porque de um lado os indigenas nem sempre nos obedecem (haja vista a curiosa e mallograda expedição de Cassange (**), em 1850 ), e de outro os inglezes nos forçam diplomaticamente a tratados commerciaes ruinosos.

N'este estado de cousas, amigo, é óbvio perguntar qual tem sido a nossa acção civilisadora nas colonias africanas, através dos tempos.

(*) Cf. Vol. CLXIV da Bibliotheca do Povo e das Escholas.

(**) Cf. A guerra dos Dembos, por Eduardo Augusto de Sá Nogueira Pinto de Balsemão. 
Vivem, pelo interior e mesmo na maior parte das nossas costas, como selvagens que, a final de contas, ainda são. Nutrem-se de hervagens e raizes, como são gehassa, gimboa, keblocota, kizaca, mandioca, bonzo e outros condimentos vegetaes. Do reino animal, comern ratos, cães, cauda de crocodilo, cobra (em algumas partes), viandas de hippopotamo, e mazenze (especie de gafanhotos), além de porcos, peixe, gallinhas, etc. Emquanto a vestuario, enfeitam-se, mas não se cobrem. Alguns pintam-se a vermelho, com tacúla; untam-se de azeite de palma; e furam sobrancelhas, nariz e orelhas, para dependurarem missangas e pennas de ave!

Já esta vae longa.

Desculpa-me uma vez mais, por ter sahido do nosso programma, devaneando em consideraçǒes.

Eu bem sei que o meu papel deve ser trabalhar para viver, descrever para te elucidar, e... ler a Biblia ou interpretar o Talmud.

No meio, porém, em que actualmente me acho, a falta de synagogas e a ausencia de correligionarios compellem-me ás vezes a dissertar, esquecendo os deveres de qualquer digno filbo de Israel.

Até breve.

Teu dedicado

Ben Zacheu 


\section{CARTA QUARTA}

Cambambe, 5 de Setembro de 1877.

Bom amigo:

Quem vive no interior de Angola, nunca deve prometter aos amigos da metropole, para não se vêr obrigado a faltar. Disse-te na minha ultima (já vae para um anno), que peln correio immediato te enviava mais noticias. Todavia, as tuas cartas teein-se succedido umas ás outras, e ainda até hoje não obtiveste resposta. Que terás pensado? Accusaste-me, certamente!

Pois, se assim fizeste, foste injusto para commigo. Se tu aqui tivesses alguma vez estado, melhor saberias avaliar a extensão do teu erro, accusando-me.

O europeu, seis mezes depois de vir ao interior, principia a soffrer de baço ou de figado, e ás vezes de ambas as cousas ao mesmo tempo. Passam a fazer parte da sua bagagem vidros de sulphato de quinina e de valerianato da mesma. Toda a espantosa actividade que lhe é inherente desapparece, sendo substituida por uma indolencia inqualificavel. Como os mercados estão mal fornecidos, e ficam muito longe,-quando nós aqui temos pimenta, acaba-se-nos o sal; ás vezes temos os temperos, mas escasseia o vinho; outras vezes nem ha vinho, nem carne, nem lataria de conservas, o que nos obriga a passar com cacusso do rio. O pão raras vezes se obtem, a não ser onde haja alguma população branca, como no Dondo, Cazengo, e Ambaca. 
Tudo isto se traduz em má alimentação para o sertanejo, que, se não cuida em si com o maior numero de precauções, definha e morre. Primeiro a negligencia accentuada, depois a dyspepsia, em seguida as febres paludosas e intermittentes, e por epilogo uma febre biliosa que o manda de presente a N'gana Zambi! Como as cousas são assim, o portuguez, que já em Portugal abusa muito do censuravel ámanhã que o Padre Antonio Vieira no seculo xvrr tanto verberou, substitue aqui, sem o sentir, o deploravel vocabulo ámanhã, pela deplorabilissima expressão "para o mez que vem".

Nós que estamos no interior, nem sabemos ao certo o dia em que o paquete sahirá de Loanda para Lisboa, nem temos a certeza se os cabindas das lanchas levarão ao seu destino as cartas que lhes entregarmos, nem confiamos na honradez de qualquer preto que, na qualidade de dispendioso carteiro, nos leve a correspondencia d'aqui a Loanda, tantos dias a pé através de tão longas distancias.

Este é o modo como as cousas por aqui se passam. Eu tenho soffrido todas as contingencias de quem por estes mattos viaja sem outros recursos mais do que os do acanhado negocio. Já sei o que é ter uma febre biliosa, nos sertões, com falta de botica, de medico e de carinhos.

A proposito, antes de ir mais adeante, gostarás que te informe dos processos medicos aqui adoptados entre os indigenas, e comnosco, quando alguma febre nos prostra na esteira.

Como saberás, a doença é aqui attribuida a feitiçarias, pelo que a adivinhaęäo e o sortilegio constituem o elemento mais essencial no tratamento de qualquer enfermidade.

Logo que uma pessoa cáe de cama, cada un dos vizinhos pensa em attribuir a qualquer individuo já morto, ou ainda vivo, as causas da lucćta ("doençan). Escusado é dizer-te que n'isto acham occasião de se vingar d'aquelles a quem malquerem, imputando-lhes o crime de cu loa ("enfeitiçar").

Reune-se cá fora da casa do doente o conselbo, afim de adivinhar o auctor e os motiros do feitiço (cu saquéla).

Isto tem sempre logar á noite.

São chamados es parentes mais proximos do enfermo, os seus conhecidos, amigos, muleques, bicas, acage, acagina, mucambas, e toda a vizinhança, incluindo novos e velhos, homens, mulheres e creanças.

Acage são as mulheres do doente, se este é do sexo masculino; tratando-se de uma enferma, é o mulumi (marido?) quem cuida da convocação para o sortilegio, ou o irrnão mais velho, na falta de pae ou xiàe. 
As acage de um homem vivem entre si em boa harmonia, tendo umas para com as outras reciprocas provas de attenção e camaradagem, na razâo directa da antiguidade. A mais antiga mulher é sempre a dona da ćasa, a patrôa, a quem as immediatas obedecem.

Acagina (*) são mulheres com quem os homens teem relações de amizade, e subsidiam, contra vontade das acage. São rivaes! Intrigam-se permanentemente, envenenam-se umas ás outras, causam emfim reciprocamente todos os males possiveis.

Chamam-se mucambas as pretas novas e bonitas que os homens resgatam ao gentio para d'ellas fazerem usos illicitos, tratando-as mais de amantes que de servas.

Reunidas, pois, todas estas entidades, chegam os quibanda que veem fazer sortilegio, adivinhar (cu saquéla).

Não desgostarás que te descreva um d'estes feiticeiros no momento de funccionar.

Trazem um panno enrolado á cintura, ou uma tanga de $l i$ condes, untada de azeite de palma, com que tambem amaciam todo o corpo nú. A tiracollo para um e outro lado, vêem-se cordas, correias e fios de contaria onde penduram o jango ( facão), a caixa de tabaco de cheiro, e a muchilla, uma especie de malinha onde veem os ingredientes essenciaes da feitiçaria (como sejam um chifre, uns boccadinhos de pelle de animal, e certas madeiras aromaticas poidas, is to é, reduzidas a pó, taes como a tacúla e a quicéca). Não falta na mencionada mala uma infinidade mais de objectos, cujo inventario completo se tornaria difticil:- mávo (certa terra), um pouco de chumbo de caça, algumas cargas de polvora, uns pedaços de colla e gengibre, etc. Ao pescoço vêem-se dependurados dois, quatro, e mais monos ou amuletos, com que têem de identificar todos os actos da vida. Se bebem, burrifam os taes iteque; se comem, dão-lhes comida mastigada; se se lavam, la. vam-se os bonecos; se usam de tacúla, ficam tintos de encarnado; se se untam, do mesmo gosam os figurões!

Poderás bem calcular, meu amigó, que estes iteque, feitos de madeira ou marfim, softrendo tantas, tão variadas e tão nojentas operaçōes, exhalam de si um aroma nauseabundo.

A cabeça dos quibandas é penteada, entrançada e entretecida com coraes e certas especies de missanga que denominam

(*) No singular Mucagina. 
Cassungo, Malia segunda (*), etc. Sobre este penteado coilocam a parte da cabeça de uma pelle de tigre ou de onça (kiba) que lhes desce pelas costas abaixo. A cara é matizada com barro amarello (Pemba), tacúla, quicéca, e farinha de milho (fuba).

Os pulsos e tornozelos do quibanda teem geralmente muitas manilhas de ferro, cobre e mesmo ouro, além dos anneis de missanga com que se adornam.

$\mathrm{Na}$ mão trazem uma espingarda lazarina, com pedreneira, e uma cabaça para aguardente. A's costas pende-lhes um surrão, ou alforges de algodào tecidos vo paiz e destinados a conduzir garrafas vazias e muitas outras trapalhadas.

Imagina tu o lindo figurino que todo este trajo offerecerá aos olhos curiosos.

Com o quibanda veem sempre os musicos portadores da puï$t a$, e um rapazinho que traz as panellas de barro onde se hão de preparar os milongo (isto é, os remedios espirituaes e os naturaes).

Antes de ir adeante já sei que devo explicar-te, por incidente, o que ha por aqui ácêrca da colla e gengibre, em que por differentes vezes te tenho falado nas minhas cartas.

A colla e a gengibre teem na provincia de Angola uma importante representação nos ainores da mocidade. Um preto declara amor a uma donzella cfferecendo-lhe um boccadinho de colla e de gengibre. Se ella acceita e mastiga, é signal de que corresponde ao apaixonado e se acha virgem. Se acceità a offerta, mas não se ntilisa, quer dizer... que já de outra vez tinha provado colla! n'este caso, corresponde aos amores, mas já não está livre de mácula.

D'aqui $C$ anrexim n'bundo : "Comer colla" (isto é : entregarse á libertinagem).

A's vezes a rapariga não recebe a offerta que o namorado lhe faz. Ertão comprehende-se que não acceita a côrte que se the offerece. $r \cap$ desenganado tem de guardar a colla para outra que se rigne acceitar-lh'a.

Vejo agnra gise tinha um certo espirito o offerecimento de colla e gengzhre qlie as ruitandeiras de Loanda me faziam quando eu desembarqu

(*) Cor aүeào de Miaria Segunda, nome dado a uma certa centaria de com. mercir. 
Estas digressões descriptivas, amigo, teem-me feito interromper o principal objecto d'esta correspondencia. Tu me perdoarás, acatando a minha boa intenção de te pôr presentes as mais pequenas minuciosidades ácêrca dos usos do paiz que vou atravessando.

Voltemos á historia dos enfermos.

Se o individuo se acha em estado muito grave, é claro que não pode exclusivamente aguardar o veredictum do sabio doutor. Emquanto, pois, lá fora se aggremia o povo, e se ateiam as fogueiras, vae elle usando de alguns remedios de uso interno e externo, como paleativo, isto é, no intuito de contem. porisar até que o sortilegio decida das verdadeiras causas espirituaes da doença. Estes desgraçados creem mais na virtude das palavras cabalisticas do que na acção de qualquer raiz ou mucilagem!

Aqui te dou nota das plantas medicinaes mais usadas, designando as pelo nome indigena, e pela ordem por que me forem occorrendo:

Dongolondo, colla, mufilu, dallu, mulongua, abutua, mubáfo, quicalango (babosa), mudianhoca (fedegoso), catalango, dongaluto, mufixi, Santa Luzia, xili, mubota, caringo, etc.

Vão-se applicando ao doente alguns d'estes remedios, que, na sua crença, deverão apenas não permittir que a doença progrida. Então, já noite fechada, principia o grande remedio! Faz-se um circo espaçoso onde apenas crepitam as fogueiras, e passeia o quibanda assumindo ares de profundo alchymista!

- Acaso gostaes da morte de F...? pergunta elle á turba, com uma voz roufenha e cavernosa.

- Cana n'gana! ("De modo nenhum!») responde o povo.

- Algum de vós se accusa de ter concorrido para a doença de F...? pergunta de novo o mesmo Quibanda.

- Cana n'gana! repetem.

- Sabeis de algum meloge (feiticeiro) a quem se possa attribuir o estado do enfermo?

- Cana n'gana! respondem. Ou alguem sae da turba, 
confessando quaesquer factos de sobrenaturalismo ou feitiçaria de que tenha conhecimento, relativos ao doente, ou que tenham relação com a doença.

O quibanda escolhe d'entre a multidão uma mulher, parente do enfermo, ou extranha. Extende uma esteira no largo, e fal-a sentar-se, com o tronco vertical, e as peruas unidas e horisontaes, formando com o corpo um angulo recto: os braços sãolhe cruzados.

Princip a um côro, ou, antes, uma gritaria infernal de todo o povo, emquanto alguns negros avivam as fogueiras, e as puïtas cumprem o seu dever, desafiando os ares com uns sons cávos e medonhos.

Veem tres pedras para proximo dos pés da operada. Sobre ellas colloca-se uma caldeira, pintada de vermel ho com tacúla, e amarrada em volta com licondes obrigados a certos e determinados nós convencio 1:aes, cuja significação e utilidade só o quibanda comprehende. Dentro da caldeira entram os ingredientes: algumas hervas (das de que acima te falei), alguma pemba (barro branco), e não sei quantas cousas mais, que constituem o segredo dos feiticeiros.

Ateia-se o lume, e a mistella entra em ebullição. O quibanda, a par d'estas operaçòes, vae dizendo palavras inintelligiveis e dando a cheirar á paciente alguns aromas exquisitos. Emquanto as cousas assim se possam, a puita toca, toca desesperadamente, e o povo canta, atroando os ares sem rithmo nem cadencia, dando apenas tempo para, de vez em quando, se ouvir algum grito de dôr, soltado lá de dentro da cobata, pelo enfermo agonisante.

A feitiçaria da caldeira fumega, enchendo o espaço de vapores aromaticos. A paciente já não está em sil A convicção da sua lei, a embriaguez causada pelo emprêgo d: s cheiros activos, a excitação dos sentidos, pela bulha estrondosa, mesclada com os gemidos do doente e grita do povoléo que se apinha, tudo isto a faz perder a consciencia do eu. Agitase, convulsiona-se, esgazeia os olhos, inteiriça os membros, dá um salto mais prompto que c da panthera: e eil-a de pé, passeando e falando ao povo, sem consciencia de si, privada de sensação, mas discorrendo, discorrendo com acêrto sobre factos certos, succedidos ua vida do doente.

Faz-se um silencio sepulcral! O povo espera pelas noticias que a possessa dará, porque, em theoria n'bunda, o en. fermo acha-se sempre em poder do Quiluno e Cassuto, ou de outro qualquer espirito maligno que o atormenta. $O$ individuo que o quibanda opéra pela forma que te tenho narrado, 
vae dizer qual é o espirito que tomou posse do enfermo, e por que razão o fez, a fim de se poder saber o modo de o aplacar ou desviar.

Cada mau espirito tem sua categoria, sendo uns mais poderosos que outros.

Os Cazumbi são deuses caseiros (por assim dizer); såo pequenos Amphitryões que só se intromettem em questiunculas domesticas, a proposito de algum copo de aguardente, ou de alguma vara de fazenda.

Os outros, porém, são poderosos agentes sobrenaturaes, difficis de aplacar, e que a maior parte das vezes teem a fôrça necessaria para causar a morte a quem d'elles anda possuido.

Em muitas d'estas adivinhações, como a que te estou descrevendo, revela-nos o individuo, porr cuja via se consulta a doença, algum mau olhado, praga rogada por inimigo, vizinho, ou mucage. $\mathrm{E}$ então... ai! da victima accusada!

Corre logo tama de ser in'loge, homem bravo, feiticeiro illegal, - e seu unico recurso é fugir d'alli, fugir para muito longe.

Ao fim de longas revelacões, a mulher ou o homem enfeitiçado, solta um immenso grito acompanhado de um pulo gymnastico, e fica no seu estado anterior aos exorcismos, sem se recordar de cousa alguma do que se passou.

O povo, muito satisfeito, diz repetidas vezes:

- Uai ia'bo! (isto é: já se foi o espirito revelador que viera descrever ao povo as circumstancias e condições da doença do enfermo).

O Quibanda expõe então aos parentes mais proximos do doente a natureza do tratamento a seguir, garantindo que a doença não progredirá mais, etc.

A binda de aguardente e a de maluvo correm em volta, por todos os circumstantes; cada qual vae vêr o enfermo, mo, despedir-se d'elle, etc., e tudo reentra no grande silencio da noite.

Emquanto, porém, a doença não decide para melhor,-dias e semanas consecutivas, a toda a hora do dia e da noite, se vêem á porta da cobata duas ou mais velhas, nojentas e hediondas, carpindo em altos brados!

Quizera ser n'esta mais extenso, tantas são as cousas interessantes que tenho visto por este paiz a todos os respeitos novo, e que, bem me parece, terá um dia importantissimas funcções sociaes a desempenhar, como vehiculo directo para a civilisação do interior do Continente Negro! 
A linha ferrea que por agora se projecta de Loanda a Ambaca (*) terá n'um futuro, que já não vem tão longe como se julga, de se prolongar, soltando a locomotiva o seu silvo imponente através d'essas immensas florestas virgens onde até agora só se tem ouvido o rugir do leão corajoso e o guinchar do macaco arlequim!

E mais não prosigo!

Cá me está chamando o meu Samba-eb, para que prepare a bagagem e parta mais para o interior, onde felizes negocios reclamam a minha presença.

Saude.

Teu amigo

Ben Zacl.eu.

(*) Já hoje está abert̊á exploração esta vila-ferrea quo ainda em 1576 não passava de projecto. 


\section{CARTA QUNTA}

Pungo, 1 de Janeiro de 1878.

Regresso de longa viagem através de todos estes campos vastos e fertilissimos. Ao mesmo tempo que ultimei negocios sobremaneira valiosos, fui notando com olhos de observador todos os extraordinarios costumes a que tenho assistido.

Antes de outro qualquer assumpto, occorre-me falar-te das construcçōes navaes.

Por esta expressão deves comprehender que me refiro ao fabrico de canôas, que representam objecto de grande importancia na vida e meios de alimentação dos povos de Angola.

Como sabes, esta provincia está perfeitamente irrigada pela Natureza que a minou de importantes rios, como sũo o Zaire, o Bengo, o Dande, o Cuanza e o Cunene (*). O que talvez ignores, porém, é que, além d'estes e muitos outros rios de que te não preciso falar, tem Angola, por aqui e por alli, como que marchetando este feracissimo solo, numerosas (e algumas muito grandes) lagôas, residencia habitual dos crocodilos e hippopotamos, e morada dos mais bellos peixes d'agua dôce d'uste paiz, como são o pargo e o popular cacusso.

Como, nas minhas ultimas digressões, mais de uma vez andei proximo de várias lagôas e rios interiores, posso com mi-

(*) Para mais minudencias geographicas, cf, O vol. CLXIV da Biblictheca do Povo e das Escolas. 
nuciosidade referir-te o resultado das minhas observaçũes so. bre a pescaria e seu principal iustrumento: - a canóa.

Conforme au que já te contei, as lagòas, rios e müge (ribeirinhas) acham-se cobertas đe muitas canôas que, seguudo a sua grandeza e uso, teem diversos nomes.

Os typos principaes são a Quimbála e o Dongo.

Lungo é termo generico para desiguar qualquer eanôa.

Quimlacila é uma canôa pequena, destinada aos usos da pescaria, e tambem serve para passar os individuos de uma para a outra margem dos rios ou das lagôas (cu tabúca).

O processo de navegação consiste no remo curto, que o individuo maneja ora para uma, ora para outra banda da canôa, ou na vara de ximbicar, feita do veio da palmeira: servem-se d'este processo quando o fundo é pouco; fincam a vara na areia, e, dando impulso, levam adeante a canôa que desliza com velocidade sobre as aguas.

Extranharás alguns vocabulos de que n'estas cartas faço ás vezes uso, os quaes offerecem para ti certa novidade.

Amigo: isto justifica-se porque eu me deixo, sem querer, influenciar pelo meio em que actualmente vivo. Devo-te explicar que os indigenas, no seu desejo de falar portuguez, usam instinctivamente de certos processos derivativos com que enriquecem a nossa lingua de vocabulos novos, curiosos, e mesmo necessarios para exprimir certas e determinadas idéas.

E' assim que por aqui usamos de ximbicar por cu ximbica n'bundo, tabucar por cu tabuca, etc.

Nem isto pode parecer extraordinario a qualquer observador estudioso. De mais... sabes tu quantos elementos peregriuos se acham introduzidos na nossa lingua, por via das velhas uaregações, commercio e conquistas em todo o mundo. Para que enumerar vocabulos d'esta natureza?

Do arabe recebemos algebra, zero, talisman, e outros; do persa temos azul, derviche, lzlaz, etc. Dos mares da China e da India nos veiu sagú, tabaco, hyson, cimitarra, sofá, mu. mia, assassino, divan, janizaro, e quantos mais?

Deixemo'-nos, porém, de philologia que, dictada por mim, cá dos confins do mundo, pouco te pode utilisar, - e passemos ao que mais te interessa.

Os filhos de Angola chamam Dongo a uma canôa muito grande, destinada a carretos, fretes, e tambem pescaria grossa.

A madeira de que se servem para a sua manufactura é a de uma grande e muito grossa arrore conbecida pelo nome de mafumeira ("m'fuma»). 
Dão-se ás vezes engraçados enganos com aquelles que ainda não estão bem praticos nos costumes e lingua indigena.

Meu caro: hoje posso-te dizer que falo de cathedra a respeito d'estes assumptos, porque muitas das scenas que te vou narrar teem passado por mim.

Ha por aqui o habito de contratar, negociar, e vender mafumeiras ainda na terra. E', pois, vulgar approximar-se de nós un qualquer preto, dono de arimo (terreno de cultura), e perguntar-nos :

- Uá sumbo dongo? "Quer comprar uma canôa grande?" (isto é : uma arvore para a construir).

o europeu, em geral, se não conhece o intuito do preto, classifica-o de tôlo, e volta-lhe as costas.

As canôas são, pois, toda a navegação do littoral e interior de Angola, além das lanchas de commercio e mais navios de véla e paquetes que percorrem a costa, na condueção de passageiros, á busca de generos coloniaes, ou em procura de mercados, onde vendam fazendas, polvora e espingardas. Só no Cuanza e no Congo se vêem algumas channinés fumegantes percorrendo o interior em demanda de cominercio, até onde a ausencia de cataractas lh'o permitte.

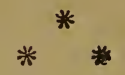

Para a construcȩão de uma canôa, o primeiro passo é abater a mafumeira, trabalho aqui muito agigantado, em que empregam dinheiro, talento e arte. Servem-se de dois processos para este fim. Com machadinhas indigenas cavam em volta do tronco, na parte inferior, um annel que vão tornando cada vez mais estreito, á maneira que excavam, até que a arvore cae. Tambem ás vezes carbonisam de tal maneira a base da mesma, que ella, não podendo mais por si aguentar-se sobre uma base assim aeteriorada, vem abaixo, tomando a posição horisontal em que, depois de trabalhada, ha de descer ao rio.

Succede em muitas occasiões que a mafumeira foi abatida longe da margem, e precisa ser conduzida para mais perto.

Esta é sempre uma operaçăo que representa quasi uma festa para o povo da localidade.

O dono da construcẹão a empreheuder convida toda a vizi- 
nhança, homens, mulheres e creanças, para, em dada occasião, se juntarem. Chegado o dia, alegra-os com aguardente abundante, e eil-os todos agarrados á canôa, impellindo-a para perto da margem, ao som de uma cantilena por vezes monotona:

\section{- Ai u eh!}

(Coro)-Mamm'eto, tat,êto, ueh! («Nosso pae e nossia mãe!») - Ai u eh!

Renovado o mata-bicho, como em Angola se lbe chama, $c$ serviço está feito, e concluido, restando apenas a construcção a fazer.

O dono do tronco chama os canoeiros (embryão dos actuaes constructores navaes da Inglaterra e America), e contrata o trabalho.

Depois de prompta a canôa, segue-se a festa do lançamento á agua. A aguardente resolve esta difficuldade. Toda a população do sitio corre ao chamamento, mediante a risonha esperança da embriaguez.

$O$ processo de que se servem para a manufactura das canôas é excavar e desbastar com pequenos machados e enchós indigenas.

Tal é a arte naval em Angola! Verdadeira infancia da arte! espelho da dos nossos avós que em tempos pre-historicos usavam de meios identicos! E do seu rude labutar, por melhoramento sobre os processos adquiridos, se foram elevando, elevando sempre, até que chegaram a produzir assombros, como são esses gigantes aquaticos que modernamente saem dos estaleiros de Albion!

Quem poderá dizer, decorridos alguns seculos sobre a nossa edade, que maravilhas sahirão das mãos dos descendentes d'estes actuaes canoeiros d'Angola?

Já que te falo d'este assumpto, não quero passar a outro, sem me referir a umas embarcações muito rudimentares, especie de canastras, muito frequentes em Benguella, ás quaes dão o nome de Bimbas. Sei-o de fonte certa: o meu Samba-eb, antes de entrar ao meu serviço, entregou-se muito n'ellas á pescaria.

A proposito: a pesca não deixará de te interessar bastante, e o ensejo de te falar n'ella parece-me dos mais azados.

Nas costas de Angola, pelo que tenho visto e pelo que me teem informado (ainda n'isto me soccorri ao meu Samba-eb!) a pescaria faz-se ao candeio, á rede e ao anzol. 
Nas lagôas, porém, e nos rios d'agua dôce, os processos empregados são quatro, a saber:- a sessie, a lua, o anzol e a rede.

Para estes tres ultimos, a canô $a$ é traste indispensavel.

Por sessie, entende se uma armadilba de forma sui generis tendendo para cylindrica, feita com ripas de bordão. Collocam-n'a á beira das rochas e bancos de areia, amarrada debaixo d'agua, pondo-lhe alguma isca dentro.

Como o apparelho só tem uma entrada que fica voltada para o lado d'onde vem a corrente, o peixe entra e vae comcr. A sahida, porém, torna-se-lhe difficil, - pelo que facil é, prssa. das algumas horas, quando já haja a maior piobabilidade de que o peixe tenha affluido, colher a sessie de repente, tirando-a da agua.

Por este processo apanha-se por aqui muito peixe e algun camarão,

A lua é usada nos bancos e baixos, chamados musceque. Consiste em fazer uma cêrca de capim, em volta de qualquer baixo de areal, deixando uma só abertura com porta corrediça. Depois que o peixe tem entrado, á procura de alguma isca, o indigena que paira proximo, dentro da sua quimbála, cortalhe a sahida, correndo o portal.

0 anzol e a rede são aqui processos de importação extranha, e, a poder de muito conbecidos, dispensam qualquer descripção minuciosa.

Nẳo é fora de proposito dizer-te que o indigena de Mossamedes fabríca azeite de peize, extrahido do cação, que abunda na costa, o qual pescam á fisga.

Da caça, um dos principaes meios de alimentação pelo in-terior, algumas informações te devo tambem dar, já que teu principal intuito é accumular dados sobre o paiz que vou percorrendo.

Nas margens dos rios e das lagôas, perseguem os crocodilos (n'qand", sengue), como animaes perigosos.

Tambem fazem emboscada aos hippopotamos, a que os europeus residentes na Provincia dão o nome de cavallos-marinhos.

O fim d'esta caça é aproveitar a carne que seccam ao sol para alimentação, e extrahir os dentes, que algum valor, ainda que pouco, teem no commercio local.

Formam armadilhas aos passaros, que são abundantes e alguns de côres lindissimas.

Perseguem o bufalo que denominam n'pacassa, as gazellas e as abadas, para comer, e os elephantes, pelo interesse da 
carne e com especialidade dos dentes, que teem grande valor, segun io sejam de marfin meião, escaravelho, ou de lei.

A caça ao elephante constitue uma verdadeira monstruosidade, não inferior á do cavallo, se alguem se lembrasse de propôr guer:a de exterminio a este tão litil animal! Pois que? prohibiu-se a escravatura negra, - e não se prohibe o exterminio do elephante, um dos maiores elementos da civilisação africana, quando bem aproveitado?

Já alguem se lembrou de levantar este assumpto n'um dos maiores parlamentos do mundo - na Inglaterra!

$O$ elephante é intelligente, manso, pacifico, soffredor, forte e corpulento! Duzentos negros, ajoujados com cargas immensas, não podem com o pêso de meia carga de um elephante. E este animal, tão precioso para os usos da permutação através de grandes distancias, persegue-se aqui com um fervor que quasi toca as metas do fanatismo!

No isolamento de relações em que ora vivo, mais de uma vez tenho confiado estes pensamentos ao meu Samba-eb! Mas... qual historia!... Tem-me elle chegado a confessar que se possuisse duas pontas de marfim de lei, uma cobata com um corredor e dois quartos, tres mucambas, seis muleques e um arimo, por pequeno que tôsse, julgar-se-hia... a creatura mais rica e mais feliz do universo! Vê por aqui quão limitadas são as aspirações d'esta pobre gente, e dize-me se no meio de povos tão rudes, mas tão innocentes, ha necessidade de viajar armado até os dentes, como vejo fazer!

Proseguindo, porém, no fio do assumpto, tambem esta gente dá caça á hyena, á panthera e ao leão, no intuito de lhes tirarem as pelles, que servem para se cobrirem, ou para as venderem, quando em bom estado. As serpentes são mortas á paulada, a toda e qualquer hora em que as encontram, comquanto os pretos usem habitualmente, por entre mattos, de um pau comprido terminado em ponta de ferro com que as furam (e a este instrumento dão o nome de chuço).

E' provavel que, depois de te ter falado da caça e da pesca, me peças muito peremptoriamente noticias sobre a cozinha n'bunda.

Ora trazes-me com isso a terreno onde posso perfeitamente respigar famosas receitas culinarias que te farão crescer agua 
na bôcea, pois que seriam mesmo sufficientes para arruinar a cozinha do Matta ou a do Baltresqui.

E seja esta materia a verdadeira chave de ouro com que encerre esta já bem comprida carta.

Deixa que te apresente um menu geral das petisqueiras indigenas.

Ahi vae:

Muqueca (peixe ensopado); bigi'o canga (peixe frito); bigi'a salacalo (salgado); muamba (môlhos); xito ia n'gulo (carne de porco, de que usam muito), o classico n'fundji, verduras, fructas, mazenze, carne de cobra, cauda de crocodilo (em alguns sertões), e n'puco (ratinhos)!

Miqueca é da cozinua das cidades : peixe do mar cozido com pão ensopado e tudo temperado com malaguetas e cebôla.

As muambas são môlhos feitos com azeite de palma, malagueta, limão, e cahombo ou gindungo (nome dado a umas malaguetinbas).

Dos mazenze (especie de gafanhotos pintados em xadrez de côres diversas), e dos ratinhos, já n'estas cartas mais de uma vez te tenho falado.

Não gostam das nossas hortaliças; servem-se, porém, de algumas outras verduras, cujos nomes indigenas são gehassa, gimloa, keblocota, kizaca, etc.

O cacusso é a principal alimentação dos que moram proximo dos rios e das lagôas. Cozem-n'o, assam-n'o, fregem-n'o em azeite de palma e de ginguba, seccam-n'o e salgam-n'o. Trocam-n'o, guardam-n'o, comem-n'o, vendem-n'o, e offerecem-n'o aos parentes, vizinhos e amigos! $\mathrm{O}$ cacusso reproduz-se com assumbrosa facilidade; e só assim se explica não ter ainda desapparecico da superficie do globo, como tantos ontros animaes, ao fim de longos seculos de uma perseguição permanente, avultada e mesmo systematica.

As naturaes do paiz em que me acho, gostam especialmente de perseguir os cacussos quando recem-nascidos. Procuramn'os na praia, no fundo das poças, e extendendo o lenço por baixo d'agua, apanham-n'os aos milheiros, cada um do tamanho de 2 e 3 centimetros. Fregem-n'os em azeite de palma, e offerecem-n'os como acepipe a seus maridos, amantes, irmãos, e mais parentes. Chamam a este prato: - acepipe de Ca n'buanza.

O n'fundji constitue o principal adubo da mesa n'bunda. E' o pão! Se outra cousa não ha, come-se n'fundji... com malagueta!

Em todas as cobatas ha uma ou duas panellas de barro es- 
peciaes d'este acepipe, que se cozinha e come de maneira muito nojenta e rudimentar.

A panella é posta ao lume com agua. Esta ferve e mettese-lhe a farinha (fuba) de mandioca ou de milho, que principia a engrossar. Deitam-se-lhe dentro algumas malaguetas e revolve-se tudo muito bem com um pau que em todas as cobatas existe, destinado a este serviço. Nem pode, entre esta gente, dizer que tem casa quem nào possuir tres esteiras, e uma panella e um pau para infundji! São aqui, estes objectos, trastes tão importantes como entre nós cadeiras, mesas e baixel!a

() tal n'fundji torna-se n'uma massa muito consistente que os eliropeus, por escarneo, chamam cólla de sapateiro.

Apromptada a mesa (isto é, depois de exterdida no chão a esteira, e trazida a panella do n'fundji e a gamella do peixe, da carne ou das hervas), cada qual acerca-se, e, sem mais lavatorio nem prévio asseio, começa a comer com as mãos, tiraudo todos com os dedos alguns pedaços da dita massa que vão molhando no oleo de palma, preparado na outra vasilha. Depois serve-se o café, e bebe-se aguardente (se a ha) ou vinho de palmeira (maluvo).

A' beira dos rios e das lagôas, criam-se ostras de agua dôce, pouco saborosas, as quaes só são aproveitadas pelos euroropeus lá residentes.

Eis o que é uma refeição indigena no interior de Angola. Conversam no entretanto sobre as intrigas amorosas dos moradores do bairro, sobre os feitiços, a legalidade do ultimo alembamento (n'lemba), etc., aguardando que chegue a noite a convidal-os ás voluptuosas dansas do Quizomba.

Não querendo por agora ser mais extenso, reservo-me para na proxima correspondencia te falar d'estes celebíes festejos dos filhos da Provincia: o Quizomba e o N'lemba.

Prepara-te para assistires commigo a este immenso pandemonio que se chama o casamento e a festa das bôdas!

Até breve.

Teu amigo

Ben Zacheu. 


\section{CARTÁ SEXTA}

Maculumby, 6 de Abril de 1878.

Meu bom amigo:

Cá me tens já de regresso a Maculumby, depois de uma.com. prida digressão por todo este interior. Vi florestas vastissimas, e ainda mais vastos areaes, tudo semeado de terras avassalladas e não avassalladas, de modo que muitas vezes me achei em logares cuja lei desconhecia. Além das muitas cobatas semelhantes ás que já te descrevi, a proposito da Ingombota, notei dois typos em tudo diversos do que eu conhecia: os cangulo, e as casas de adobe.

Por cangulo entende-se um pequeno castello. (*) Nâo sei por que motivo dão um tal nome a umas barracas pequenas e infectas, de feitio redondo, terminadas em bico, e forradas de capim, tendo uma só abertura, onde põem uma especie de porta feita de canniçado.

Alli dentro virem ás vezes familias numerosas!

$\mathbf{E}$ todos lá pernoitam, embora o espaço não comporte, hygienicamente falando, um só individuo a dormir! Pois alli ficam pae, mãe, filhos, filhas e mais parentes, além do muleque, etc., todos debaixo de mosquiteiros grandes, immensos, respirando um ar mephytico e viciado pelo brazeiro que perma-

(*) Litteralmente $C a$ (diminutivo) e $N^{\prime} g u l a$ (eporcos). Por formaçåo semea thante teem cangombe, canbuanza, etc. Não chegámos, porém, a comprehonder qual o tropo que deu a cangulo o sentido de equena cobata.. 
nece ateado durante a noite para aquecer o recinto e afugentar os insectos e reptis!

Notei tambem algumas casas de adobe, que consiste n'uma especie de tijolos de barro em prisma quadrado, faciados e amassados com agua, e endurecidos ao sol. As paredes são feitas collocando estes tijolos uns sobre os outros, deixando em aberto os logares das portas e janellas.

Faz parte de qualquer cobata uma especie de quintal emparedado com ramas de melela (amoreira indigena); um telheiro onde se faz a cozinha, um chiqueiro para porcos, e a mutálla.

Dão este ultimo nome a um telheiro assente sobre paus de melela, destinado a guardar as panellas, milho e outras cou. sas, em sitio alto, para que de noite os animaes não venham comer e lamber o que se conserva em retem.

Além das casas que te tenho descripto, ha construcções, ainda que rudimentares e tôscas, feitas de pedra e cal; mas, na maior parte, pertencem ás feitorias europêas, que se apresentam espalhadas, por aqui e por alli, em todo o interior de Angola.

O pessoal de qualquer casa é sempre numeroso, para em dados momentos haver gente para construir uma cobata, derrubar uma arvore, fabricar um quintal, etc.

E podem as cousas passar-se de tal modo, por haver para este povo a maior facilidade na alimentação e no vestuario que, como já sabes, é do mais rudinnentar.

Comquanto não deseje tomar-te muito tempo com este assumpto, vou tentar descrever-te, ainda que summariamente, os muitos e variados modos de adornar e vestir, usados pelos difterentes povos que tenho conbecido até agora n'esta provincia.

O panno é a forma generalisada nos territorios avassallados.

A tanga propriamente dicta é a forma classica, a forma tradicional, por assim me exprimir.

Durante estas ultimas viagens tenho notado que os indige. nas usam nas festas de uns pannos de riscado a que chamam maclusso e tafaxis, empregando zuarte e algodão para os trabalhos da vida.

Ha, porém, uma verdadeira pragmatica na maneira de traçar a roupa sobre a cintura, sendo certo que pelo modo de pôr um panno conhecem os práticos a categoria e patria a que qualquer individuo pertence.

Nos paizes não avassallados, nos sertões mais reconditos, 
como Bihé, Cassange e Bailundo, a forma usual, segundo observei, é a tanga propriamente dicta, quando em viagem,porque nas suas senzallas a gente môça anda no estado de nudez primitiva.

Durante as minhas ultimas digressões, um outro objecto me prendeu em especial a attenção. Refiro-me ás caravanas commerciaes.

A caravana representa em Angola o modo facil de chegarem os generos coloniaes ás costas de mar, ou a qualquer ponto de commercio, em territorios que não são cortados de estradas, nem de vias acceleradas. Se não fôra a caravana, custoso nos seria o marfim, a borracha, a cera, etc.

Entre parenthesis, permitte-me, como negociante e ainda mais como portuguez, uma consideração de ordem politica. Estes preciosos generos coloniaes, que deviam seguir directamente para Portugal, onde seriam manufacturados pelos processos da moderna industria, dirigem-se quasi todos para Inglaterra por uma habil influencia diplomatica que os nossos alliados sabem maravilhosamente desenvolver, no sentido de garantirem o melhor possivel os seus interesses.

Nós, não dando uma esp zcial protccção á industria nacional e aos productos coloniaes nossos, perdemos os melhores interesses que das colonias poderiamos auferir, deixando seguir para Inglaterra e tambem para os Estados-Unidos, por uma bagatella, a nossa borracha e marfim que depois importamos convertidos em artefactos que nos custam um dinheirãol Já, por esta falta de senso politico na legislação commercial, temos visto desviar-se para o extrangeiro o commercio todo do Brazil que devia ser nosso, como os Inglezes se souberam aproveitar por medidas diplomaticas do da America do Norte.

Incrivel parece na verdade que o Brazil tenba commercio para sustentar companhias de paquetes francezes, inglezes, hespanhoes, allemães e italianos, e não possamos nós ter uma só carreira portugueza de vapores para as terras de Santa Cruz!

Pedindo-te me desculpes estas considerações de incidente, que proveem da indignação profunda de um portuguez contra os erros politicos da sua patria, prosigo no de que ia tratando.

Como nos sertões poucas são as casas de negocio (os aviados) e nenhumas as feitorias, tem o indigena de carregar do interior os nroductos que deseja permutar, e conduzil-os até ao mercado mais proximo, onde haja casas de commercio e feitorias. 
O trajecto, porém, ás vezes é longo, e quasi sempre arriscado, ou porque tenham de pagar tributo a certos sobas, que o exigem, pelo direito de transito, ou porque atravessem florestas infestadas de animaes ferozes, ou mesmo porque precisem de se precaver contra os salteadores que são muito numerosos no interior de Angola, e ainda mais, segundo me affirmam, no de Benguella.

Para resistir a estes attritos, costumam combinar-se todos os de uma certa regiào, que tenham negocios a fazer, e preparam a viagem para um dia fixo em que deverá realisar-se a partida.

Reunem-se, organisando as suas cargas, onde levam o producto que pretendem trocar, e os mais necessarios para a sua alimentação.

Estas caravanas jornadeiam ás vezes quinze, vinte, e trinta dias, antes que cheguem ao ponto a que se destinam. Teem diversos nomes, segundo as differentes localidades d'onde partem.

Chamam-lhes Quibuca, Ombaca, Quipambala, Hendo, e ainda outros.

Elegem um chefe que os guia durante a viagem. Enfileirados uns atraz dos outros, formam uma linha de carregadores, às vezes muito comprida.

Já tenho visto quibucas com tresentos e quatrocentos carregadores.

Viajam de sol nado a sol posto, fazendo Quilombo (isto é, acampamento para comer e descançar). De noite accendem fogueiras em volta da caravana, afim de se livrarem dos mosquitos (onde os ha) e se precaverem contra os ladrões e animaes ferozes.

Mal podes lá na metropole, n'um meio totalmente diverso d'este, fazer idéa do phantastico aspecto d'estas immensas fileiras de homens, alinhados um a um, formando longas car. reiras que desenham as mais exquisitas curvas através do ondulado dos caminhos accidentados.

Anoitece. Então fazem alto em logar que para isso lhes parece mais azado. Arreiam as cargas, buscam lenha e accendem immensas fogueiras, cujas labaredas ameaçam lamber o negro céo. Umas vezes celebram os prazeres da viagem, as felicidades do negocio, ou as bellezas de suas mulheres, em canções altilıquas. Outras vezes as caldeiras fumegam, o peixe sêcco crepita sobre as brazas, a farinha sae das saccolas, os instrumentos soltam as suas notas alegres, e passase a noite entre o comer, dormir e tocar! Dôce vida, por con- 
stituir, na sua rudez, o maximo das aspirações d'esta pobre gente!

Já esta vae maior do que tensionava,- tendo, aliás, faltado a) programma que te annunciara na minha anterior.

Prometto desempenhar-me d'elle cabalmente na minha proxima correspondencia, que será breve. E, como lenitivo aos meus pesares, atrevo-me a contar com a tua bem proverbial benevolencia.

\section{Adul Adonai kitou...}

Por aqui vês que nâo sou avêsso aos versiculos da minha religião, dos quaes ainda me recordo.

Embora assista a tantos e tão variados ritos gentilicos, nem por isso deixo a miudo de recitar os mais preciosos psalmos do grande David.

Até breve.

Teu

Ben Zacheu. 


\section{CARTA SEPTIMA}

Sanza, 2 de Jareiro de 1879.

Meu caro amigo:

Sinto que as febres me perseguem cada rez mais.

Não sei se me será possivel prolongar ainda por muito tempo a minha residencia na Provincia. Agora que os negocios principiam a sorrir-me, vem a Molestia postar-se-me á cabeceira do leito, convidando-me a tudo abandonar, para me recolher a um clima que seja mais benefico. Contingencias de quem se não acha garantido por uma grossa fortuna!

Antes mesmo de vêr o que se vae seguir ao estado febril era que ora me acho, devo dar-te uma idéa geral dos actos particulares, ou, melhor, da vida civil d'este pobre povo.

Do nascimento e morte já tens recebido alguma noticia por estas cartas.

O parto feliz é sempre seguido de uma dansa e banquete de festejo.

Preciso, porém, juntar algumas notas ao que, a proposito da colla e gengibre (cariquezo), já n'uma correspondencia anterior te disse dos amores em Angola.

O namôro é um producto perfeitamente natural, e que nada admitte inesmo de artificio. O namôro não se planeia, nasce espontaneo entre dois seres de sexo differente: é uma especie de sympathia nervosa! Por isso tenho encontrado este preliminar das uniǒes conjugaes em todos os povos e raças que tenho observado, tanto na Europa como em Africa. Simplesmen- 
te, a forma de sustentar o namôro differe de paiz para paiz, de logar para logar.

Em Angola não ha os recatos, as occultas, os mysterios de que, muitas vezes, em Portugal se originam os grandes escandalos.

O namôro em Angola é quasi sempre principiado no Qui$z o m b a$ (dansa indigena caracteristica), e terminado no n'lemba (preço da virgindade) pago aos paes ou irmãos da noiva.

O Quizomba tem sempre logar nos quintaes largos, e é thema obrigado quasi todas as noites. Por isso, seja qual fôr a hora em que se viaje pelo interior, depois de sol-posto, sempre se ouve aqui ou acolá a puïta roncando seus roncos monotonos, e a cantoria dos bailarinos. $O$ extrangeiro, que não conheça os costumes, perguntará a si mesmo se atravessa por paiz de gente, se por terras de bruxas e feiticeiras! E' porque o preto ama a ociosidade,-e o pouco trabalho que faz, é feito com o pensamento no Quizomba onde perderá a noite, vendo a sua amada, contratando as suas entrevistas, discutindo o preço do n'lemba, dansando e embriagando-se. De manhã, onde ha feitorias ou aviados, á hora em que o europeu abre o estabelecimento, vão-se os negros recolhendo da orgia!...

Todos amam o Quizomba, como forma nacional, como uso inveterado no paiz e perpetuado de paes a filhos: mas os ve.inos e velhas temem sempre por horas mortas a quéda de alguma virgem ou a morte de algum m'loge!

Effectivamente tanto o Quizomba tem de sympathico como de horrivel! Que se faz alli? Distrahir, dansando uma dansa voluptuosa, bebendo uma aguardente demasiado toxica, desperdiçando as horas em que o descanço é mais necessario, dando, emfim, pasto á exaltação dos sentidos, provocando adivinhas, sortes, juramentos e... feitiços!

A dansa consiste em formar uma roda, d'entre a qual saem uns pares que bailam no largo, dois a dois, tomando ares pro vocadores e posições indecorosas, em que a voluptrosidade discute com a insolencia as hnuras da primazia.

Os que entram na dansa cantam em côro a que os dois pares respondem em canções allusivas a todos os factos conhecidos da vida privada dos presentes e dos ausentes. Alli se discute o numero de acage, acagina, e micamba, de cada um dos vizinhos; alli se ventila a pureza ou impureza de algumas filhas de farnilia!... Chegam as cousas ás vezes a estado tal, que de manhã, algum dos que deviam regressar a suas casas, vae para debaixo da terra... ébrio, n'umas vezes, e morto á paulada, n'outras! 
Servem-lhes de illuminação duas ou tres fogueiras ateadas no largo; por tecto teem a ramada das palmeiras e mafumeiras, além do céo... esse esplendoroso céo d'entre-tropicos que sorri para nós durante os doze mezes consecutivos!

Aquenta-os pela noite adeante a aguardente e o movimento... o movimento voluptuoso, agitado, com tendencias para turbilhão!

Esta é a monographia do Quizomba de Angola, do festejo genuinamente indigena, que eança, moe, enebria, causa vertigens, allucina... mata, n'uma palavra!

N'estas festas os velhos anicham-se no ca'ng lo mais proximo, e alli fumam a narcotica liamba, emquanto assam nas brazas algum cacusso, bonzo e bombó (batata dôce e mandioca). A isto chamam cu xinguilé, porque crêem que do recolhimento ao lar provém a clareza e solemnidade dos pensamentos inspirados pelos calundús benevolos!

Dizia-te, pois, que no Quizomba se origina o namôro. Vamos agora seguil-o, até a consummação do ideal d'esta pobre gente - a posse da mulher e a procreação da especie.

Aqui o casamento é legal quando a mulher é pedida e concedida por commum accôrdo das familias, e depois de pago o competente n'lemba. Em alguns pontos da Provincia, a categoria do individuo é julgada pela quantidade de cabeças de gado que possue. N'outros sitios, com especialidade nos sertões, a maior ou menor quantidade de terra e de escravos distingue de preferencia os homens. Ha, porém, logares onde o individuo se aprecia pela maior ou menor perfeição corn que fala o portuguez. Os d'este numero, para fazerem melhor valer os seus meritos, pedem uma mulher a seus paes ou irmãos, por via de uma carta de que são portadoras duas velhas - as comadres ou intermediarias que patrocinam o negocin. $\mathrm{H}$, para estes pedidos, phrases muito extraordinarias, já consagradas pelo uso, formando, por assim dizer, uma especie de codigo de palavras tabelliôas dos apaixonados. Podia, por curiosidade, dar-te um rascunho que te servisse como de es. pecimen do modo de tratar por aqui estes negocios: limito-me, porém, a referir os pontos principaes sobre que versam estas cartas, por assim dizer, jocosas.

O pretendente allega habitualmente os seus meios, o numero de cabeças de gado que tem, ou as braças de testada dos seus arimos, o numero de almudes da sua colheita de azeite, etc. Seguem-se a isto as suas recommendações, parentella e qualidades pessoaes. Depois a declaração amorosa, e por ultimo... receio fazer-te rir, ao declarar-te a phrase consigna- 
da para pedir as filhas em casamento! Emfim, lá vae. Pedemn'as... para tracios licitos!

A primeira vez que vi rascunho de uma d'estas cartas, por milagre não me desfiz em gargalhadas. Os portuguezões que usain d'este processo, presumem muito de si mesmos.

Os que mais o empregam são os filhos de Ambaca, grandes manipuladores de charutos, profundos jurisconsultos e habei demandistas. O filho de Ambaca nâo pode ligar quatro phra ses em que não cite oito artigos da Novissima Reforma, seisdo Codigo Penal, tres do Civil, e um, pelo menos, da Carta Constitucional!

São tendencias! Todavia é certo que o Ambaquista, se se educar em boas escholas, deve ser um grande homem: e aqui te digo (desculpa a tolice!) que não estou muito convencido das relações do angulo facial com a intelligencia, princípio aliás muito acatado pelos eruditos, e quasi irreductivel, segundo a doutrina dcs modernos anthropclogistas.

0 angulo facial dos Ambaquistas é accentuadamente agudo, o que não obsta a que elles sejam os mais industriosos, os mais perspicazes, e os mais trabalhadores d'entre os varios povos que por aqui tenho observado. Fazem cachimbos, bancos, trastes de madeira com embutidos delicados de osso e marfim; tecem esteiras e algodão com muita arte, preservam perfeitamente as pelles de animaes e aves raras, manipulam tabaco, imitando o europeu, etc.

Voltando, porém, ao fio da descripção, sabe que o facto de um pae ou irmão receber um pedido, por escripto ou por via das intermediarias, representa sempre um grande acontecimento na familia.

Reune-se conselho! Está presente a virgem, o pae, a mãe, os irmãos, os vizinhos e amigos, e o n'ganga (c grande feiticeiro).

Ahi se discute a conveniencia ou inconveniencia de entregar a filha, a importancia do requerente, o valor da boda, e o preço do n'lemba.

Dá-se este nome ao preço por que o noivo obterá a sua consorte. Varía desde um insignificante valor (como o de um garrafão de aguardente e quatro macetes de missanga) até a importancia de muitas peças de fazenda, barris de bebida, libras de polvora, armas, fatos e coraes.

A's vezes pedem-se... (para tractos licitos) creanças lecemnascidas, as quaes, quando concedidas, ficam em casa dos paes, ou são entregues aos parentes do noivo, até a edade dos doze annos. 
Estes contratos, porém, só se fazem mediante a condição de um avultado n'lemba que é immediatamente pago.

Quando a mulher já tem edade de ser entregue ao que a pretende, depois de satisfeito o n'lemba, ainda decorrem tres dias antes do noivo a $r$ ceber em sua casa. E' este urn periodo de purificaçãol 0 medico-feiticeiro faz muitos exorcismos e remedios espirituaes á coiva, dando-lhe certas beberagens, e o balsamo dos seus conselhos, para que ella conheça os deveres de respeito e obediencia que tem para com seu marido, a obrigação que lhe assiste de cultivar mantimento e tabaco, cozinhar, tolerar as mucambas da casa, etc.

O noivo, por sua vez, ergue a cobata onde passa a viver no novo estado; adquire caldeira para cozinhar, pilão para pisar milho, café e denden, fiualmente boas esteiras, quibáca e estrados.

A conducção da noiva á casa de seu marido é sempre uma grande festa! Junta-se muito povo: e todos capricham em ter a honra de carregar aos hombros algum boccadiuho a tipoia ou rede em que a noiva vae, envolvida nos seus melhores pannos de musselina e enfeitada com os seus mais lindos adornos!

$\mathrm{Na}$ casa do marido apinha-se o povo á espera da chegada da consorte. Os cangirões de aguardente passam de mão em mão; a puïta solta seus roucos sons, a buzina atrôa os ares convidando toda a vizinhança para o Q:izomba voluptuoso, e as velhas, acocoradas na cozinha, esmeram-se no preparo dos mais exquisitos acepipes da cozinha n'bunda.

Chega a noiva! Extendem-se as esteiras pelo chão, e principia o banquete, emquanto os serviçaes da casa desafiam á orgia com suas libidinosas canções e repetidas salvas de espingarda!

Logo que anoitece começa o Quizomba do noivado, para cujo festejo ha umas formas de dansa obrigada a posiçóes typicas e allusivas, que denominam cu quina.

Quando a noite já vae fechada, escurece tambem para os noivos, que recolhem aos seus aposentos, deixando ao povo a tarefa de festejar a boda até pela manhã ao a! livre!

Nåo queria encerrar esta correspondencia sem me referir a um costume, aliás caricato, que muito diz sobre as noções do direito natural d'estes povus.

O n'lemba é o preço da virgindade: os paes recebem-n'o e guardam-n'o intacto até o dia seguiate ao do casamento em que o noivo, por um meio estabelecido em toda a Provincia, informa sobre as occorrencias que possam preuder com a sua 
dignidade. 0 barometro usado para conhecer a temperatura da reputação da noiva, costuma ser uma botija que o marido envia ao sogro na manhã seguinte ao dia do casamento, cheia, meia, ou vazia. N'este ultimo caso, o n'lemba é restituido por inteiro ao noivo que nunca mais fala com o sogro, embora continue na posse da filha. Se elle se recusa á entrega dos objectos recebidos, é causa de uma immensa demanda, em que se lança mão dos juramentos n'bundos, como são o n'bulungo e outras beberagens d'onde quasi sempre resulta a morte.

Perguntas-me, certamente, como estou tão bem informado dos mais minuciosos segredos d'este culto de amor em Angola. E' facil responder-te. Se eu queimo perfumes no altar de Jehovah, Deus d'Israel,-o meu Samba-eb (que já conheces), por ser muito novo, sacrifica ao Amor! O endiabrado menino tem-o ferido muito a miudo com suas settas, e eu tenho sido o seu Mercurio n'este negro Olympo.

Como fazer-lhe sentir o meu grande reconhecimento pelos serviços, aliás valiosos, que me presta, senão coadjuvando-o nas suas aventuras amorosas?

Qual é a historia da mocidade, em todas as raças de todos os paizes do globo? 0 amor!

No fundo das mais intimas paixões, na historia dos grandes crimes, na psychologia dos mais celebres suicidas, busca, proeura, investiga, que lá acharás, ainda que ás vezes mascarado, o Amor!

Este travesso, não sei por que, anichou-se, cá pelo interior, no coração do meu Samba-eb. Elle tem-se acolhido a mim; dispenso-lhe sempre a minha protecȩão, e acho-me, sem mesmo o procurar, de posse de todas as peripecias que por aqui occorrem sobre a materia.

N'isto faço ponto. Recolho-me n'este momento, cheio de calefrios insupportaveis. Oxalá não sejam os prenuncios de alguma horrivel perniciosa que me envie para casa de $N^{\prime}$ Gana Zambi.

Saude! tanta te desejo, quanta para mim cobiço.

Teu amigo

Ben Zacheu. 


\section{CARTA OITAVA}

Loanda, 6 de Maio de 1880.

Meu amigo:

Com grande pesar meu, tenho de interromper (quem sabe por quanto tempo?) estas correspondencias, que afinai parece terem-te interessado bastante, a julgar pelas tuas cartas.

A Doença, en!idade negregada contra quem, a despeito de toda a sciencia moderna, nem sempre temos poder, obrígoume a abandonar todos os negocios que, se proseguisse n'elles, me tornariam talvez senhor de uma fortuna relativamente colossal. Não succederam as cousas, porém, como eu esperava. Já do final da minha carta anterior o terás previsto. E' bom que desde já te desengane. Estou prestes a abandonar Angola; d'aqui vou fazer prôa a Cabo Verde; e quem sabe depois? Podes, porém, contar com a minha collaboração, não só de lá, como de toda e qualquer colonia longinqua a que aporte.

A narração das peripecias do meu regresso a Loanda é provavel que te interesse. Seja esta, pois, a minhia ultima datada de Angola. Farei por te interessar, e ao mesmo tempo acabarás de avaliar a vida pelo interior da Provincia.

Entremos em materia.

Os negocios, como te tenho dicto, deram fim, porque as febres, apoderando-se de mim, impossibilitaram-me de trabalhar mais pelos sertões recuados onde tanto tempo me tinha já conservado.

Quiz regressar. Aonde? Não o sei. No interior não podia eu 
mais permanecer. A minha historia, n'este ponto, é egual á de quasi todos os europeus que veem tentar fortuna pelo interior. Prosperam, medram: e, quando já proximos de attingir o seu ideal, a doença intima-os a morrer ou retirar.

Depois de liquidados os meus negocios, do Sanza (onde ultiunamente me acbava) desci até Cazengo em boi-cavallo. D'ahi vim em maxilla até ao Dondo, grande emporio de todo o commercio do interior. Esperava eu por vapor que me trou. xesse a Loanda. Estamos, porém, no tempo das séccas; o Cuarza é agora pouco navegavel, pelos muitos areaes que pelo meio do rio se formam. Esperei, esperei muito. Entendi, porém, que mais facil me seria a mim, sertanejo experiente e habituado ás lides africanas, tomar uma canôa e quatro pretos que me conduzissem ao Cunga, onde, com certeza, acharia vapor.

Fretei um dongo: e, depois de convenientemente installado com o meu Samba-eb e quatro ximbicadores, dispuz-me a seguir viagem.

Sabes que Samba-eb me tem sido, além de creado fiel, um verdadeiro amigo; além de me ser grato, tornou-se-me dedicado para a vida e para a morte: por isso os seus desejos teem sido para mim quasi ordens.

Todos gostam de abusar da complacencia de um sujeito.

Um negociante, que precisava de fazer conduzir até o Cunga oito barris de azeite de palma, quiz utilisar se de mim, por intermedio do meu creado. A velbacaria tambern cá pelo interior de Africa fioresce, tanto ou mais do que em Portugal.

O preto serviu de empenho para o caso; foi como se em Portugal se procurasse recommendação de algum deputado ou commendador para qualquer ministro.

E o caso é que o negociante conseguiu o seu intento. Sam. ba-eb pediu-me, eu accedi: e os barris cheios de azeite, fluctuando na agua, foram amarrados ao dongo, quatro por banda, atrazando a viagem e difficultando o serviço de ximbicar.

Lá fomos rio abaixo com destino para o Cunga. Semi-nu por causa do calor, recostei-me á ré do barquinho.

Sarnba-eb improvisára uma especie de toldo, com ramas de palmeiral, e assim seguimos viagem, evitando os rodomoinhos que ás vezes são perigosos em todo o Cuanza, e procedendo ao arduo trabalho de pôr a nado a canôa que, de momento a momento, encalhava nos baixos de areia, por alli muito frequentes.

A viagem era trabalhosa, e os barris de reboque ainda mais a difficultavam. 
Tinhamos passado o Mucoso: avistáramos o Quemby e o despenhadeiro de Mlassangano, em eujo cimo se contornavam os restos das velhas construeções alli traçadas por Paulo Dias Novaes e pelos capitães de Salvador Cori eia.

A margem esquerda desdobrava-nos aos ollos o majestoso panorama das immensas florestas da Quissama que em outros tempos ros foi avassallada.

Iamos sempre descendo. Samba-eb sacudia-me os mosquitos; os pilotos governavam a navegação; e ell, recostado o melhur que o logar m'o permittia, fumava no uneu cachimbo indigena, e extasiava-me perante $c$ aspecto grandioso da Natureza, em toda a sua pujanças e luxuria de vegetação.

Os muitos e engraçadissimos ziguezagues do cur'so do rio, os frondosos palmares e coqueiraes das margena, as caprichosas formas dos bancos de areia, as ilhas movediças de capim e matta que veem continuanente rio abaixo, até se precipilarem no ('ceano, tudo prende a attenção do viajante: n'uquellas luxuriantes regiões do Cuanza.

A margem direita é occupada por terras de Massangano, Muxima e Calumbo (*): terrenos muito baixos e planos, que as aguas, na cheia, invadem, abrindo vastas áreas navegaveis que estabelecem uma intima communicaçáv cutre o rio e as lagôas proximas.

De noite a navegação é habitualmente interrompida, porque o hippopotamo ou cavallo-marinho e o erocodilo ou jacaré, como vulgarmente lhe chamam, tornam-se perigosos.

Ia já anoitecendo. Os pilotos ximbicavam coun fôrẹa, porque era urgente chegar ao Cunga antes do amanhecer. Receavam affrontar os perigos de uma viagem nocturna. Eu, porém, estimulára-os com alguns copos de aguardente e a promessa, para elles sempre risonha, de os presentear com uns macetes de missanga com que, no termo da viagem, brindassem as suas acage.

Ximbicavam, pois, com fôrça, em vista da proposta... e do medo! Lu ignorava os perigos que corria. Mal pensava eu os riscos a que se expõe quem desacauteladamente se mette a navegar de noite em canôas pelo rio Cuanza, cujo leito humido se acha povoado de monstros verdadeiros e phantasticos que saem fora d'agua ao ataque das prêsas que encontram.

A principio todos cantarolavam para animar a faina do ser-

(*) Comquanto o presidio de N. S. de Muxima esteja ericravado em terras de Quissama, é certo que entre Massangano Calumbo ha territorios na margem direita, governados pelo chefe de Muxima. 
viço. Samba-eb continuava-me abanando por causa do calor e dos mosquitos que, nos rios de Angola, constituem depois do sol-posto, como já te tenho dicto, um verdadeiro flagello.

Iamos a este tempo navegando por entre um tapete de capim verde que cobria as aguas, n'aquelle ponto muito baixas.

De repente, os pretos interromperam a cantarola, para falarem em voz baixa.

Não entendi perfeitamente o que diziam; notei, porém, o facto, $t$ percebi que alguma cousa nova ia occorrendo. Mais se me despertou a attenção, ao observar que Samba-eb se distrahia do trabalho de me abanar, para, quasi em segredo, conversar com os pilotos.

Attribui, todavia, o caso a alguma bagatella insignificante, $\mathrm{d}$ is muitas com que os indigenas da Africa Austral se costumam prender. Despreoccupado de tudo, enchi o meu cachimbo e accendi um phosphoro.

Samba-eb, mais veloz do que o raio, corre a mim, precipitase, e apaga-me o phosphoro entre as suas mãos, ao mesmo tempo que me grita, em convulsões de terror:

- Gimuna, 'ngana iáme! ("Apague, senhor meu!»)

- Que é isso? perguntei, entre a indignação e o receio de que já me haviam contaminado.

-'Nguvo, 'ngana! ("O cavalio-marinho, senhor!»)

-Onde?

-Iná, 'ngana! ("Além, senhor!»)

E fez-me descobrir, através dà escuridåo de uma noite toldada, a enorme cabeça de um hippopotamo que, postado nos baixos; dentro d'agua, a uns vinte metros de nós, estava a pastar, atroando os ares amiudadas vezes com seus medonhos estrugidos.

Amigo, os cabellos eriçaram-se-me. Lembrou-me se, fugindo á morte por doença, viera procural-a por desastre!... Surpresas d'estas são communs no interior da Provincia.

O cavallo-marinho! Várias vezes ouvira por aqui falar d'este monstro. Em geral, conta-se de todas as feras d'A frica que ellas fogem da luz. Infelizmente com o hippopotamo succede o contrario: procura-a, approxima-se d'ella! Por isto, Sambaeb me apagára o phosphoro.

- Que fazer? perguntava eu, entre as brumas de uma noite sem luar nem estrellas.

- Esperar, me respondiam. Esperar, senhor; esperar muito quieto até pela manhâ!

Desconsolador alvitre! Achavamo'-nos entre capim enchar-

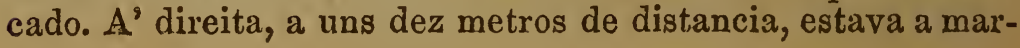


gem do rio, toda alagada, como se fôra a continuação do mesmo rio.

Os uivos repetiam-se; o medo recrescia, e o nosso mal-estar era indescriptivel. $\mathrm{O}_{3}$ mosquitos tornaram-se legiões que nos mordiam e torturavam a todos os momentos.

Não nos era facil approximar de terra, não só pelo reboque dos barris, que não podiam romper, atrelados á canôa, através do denso capim, como pelo receio de attrahir a nós o ataque dos cavallos marinhos.

Propuz um outro alvitre, de que geralmente aqui se usa em casos semelhantes. Amarrámos ao capim os barris de azeite de palma,-e, assim separados, fomos mansamente rompendo até chegar ao porto mais proximo. Novas difficuldades se nos offereceram! Não havia desembarcadouro preparado; tornava-se-nos necessario trepar.

Mas como fazel-o?

A luz não nos era permittida! e quem nos garantia que nåo estivesse algum crocodilo alli emboscado, para nos apresar, aproveitando-se das trevas!

Samba-eb saltou adeante. Eu segui-o, cheio de susto e difficuldades.

- Terral clamei. Estamos salvos!

Verdadeira aspiracão, porque na realidade os perigos ainda não haviam serenado. Achei-me no meio de uma terra toda alagada, nas condições mais extraordinarias que tu possas imaginar.

Descalço, mal coberto de roupão de chita e calças de enfiar (como aqui se usa), o estylete do mosquito atravessava-me a fraca roupa, e sugava-me no meio de incómmodas ferroadas.

Continuámos a ouvir os rugidos do cavallo-marinho, cada vez mais repetidos e tambem mais proximos.

Depois de todos seis nos acharmos finalmente em terra, cada qual alongou a vista em diversas direç̧ões, como que a pedir á escuridão um abrigo.

Nem uma luz se distinguia! Quizemos accender fogueira, já que em terra não seriamos atacados do hippopotamo; mas o capim estava todo encharcado; nem um pau de lenha! nada! bata.

Resolvemos percorrer a margem, á busca de alguma co-

Ainda bem não dera dois passos, quando soltei um grito, porque me faltára o chão debaixo de um dos pés! Era um bu. raco de dois decimetros de diametro onde o pé e perna se me sumiram até o joelbo. 
Quasi simultaneamente ouço um grito de Samba-eb, a quem por seu lado succedêra o mesmo.

Os quatro pilotos gritaram, convidando-me a não proseguir mais. A cada passada que davam, tambem elles se sumiam em semelhantes buracos.

Parecia-me no mundo das fadas! Que milagres! que mysterios estes que me fôra concedido sondar, na terrivel noite da minha ultima viagem pelo interior!

Eu quiz proseguir; Samba-eb, porém, instou commigo para que o não tizesse, preferindo ir elle adeante á descoberta. E foi!

No entretanto, os pilotos haviam-se approximado de mim. Accendi com difficuldade um dos poucos phosphoros sêccos que ainda me restavam, e, depois de examinado o terreno, reconhecemos que os buracos em que as nossas pernas se sumiam, eram as pégadas dos numerosos cavallos-marinhos que por alli transitavam e cujos rugidos nos faziam estremecer a cada momento.

Estavamos no trilho dos hippopotamos; era mistér evitar aquella situação.

Samba-eb fôra adeante e nós seguimol o. Poucos momentos decorridos, ouvimos um baque de corpo na agua, um grito, e a bulha de quem nada, esbracejando apressado!

Dei mais um passo para tomar conhecimento do occorrido, mas senti-me precipitado da altura talvez de bons dois metros!

Samba-eb, já da outra banda, gritava-me:

-O muïge, "nguna! Lenguluca! (“Ribeira, senhor! fuja depressa!n!

- Quingando alla cu iza! ("Ahi veem os crocodilos!»)

Cahiramos na ribeira,-e tornou-se-nos necessario nadar o mais depressa possivel, afim de evitarmos o jacaré que por alli é muito frequente.

Passámos felizmente a salvo, e estavamos livres dos dois grandes inimigos do rio Cuanza!

Ainda era, porém, relativamente cedo; e a noite ia tornarse insupportavel, no meio das trevas, soffrendo os ataques dos mosquitos, e talvez a visita incómmoda e perigosa da onça e do lobo, ou mesmo a mordedura de alguma serpente venenosa, das que são muito frequentes nas margens d'aquelle rio.

Todos foram á busca de combustivel; só muito longe nos foi possivel achar lenha e capim aêcco. Chegou finalmente! Accendemos então uma immensa fogueira, cujas labaredas ameaçavam lamber as nuvens, e ao clarão vimos que a gran. 
de distancia em volta não achariamos uma unica cobata onde nos abrigassemos. Alli resolvemos pernoitar, sobre a terra encharcada, occupando o tempo a contar historias, e assando cacussos sêccos.

Alongando a vista para o rio, quando as labaredas nol-o permittiam, viamos, não um, mas tres cavallos-marinhos, postados como nos tres vertices de um triangulo cujo centro era occupado pelos oito barris de azeite de palma.

Longa e incómmoda foi aquella noite, majestosa pelo proprio horror que nos inspirava.

Pela madrugada vimos alguns hippopotamos que passavam como em respeitosa continencia, a certa distancia, deslizando vagarosamente e cheios da sua medonha majestade para as lagôas onde, durante o dia, fazem residencia.

Quando já era bem claro e o sol nado, tivemos occasião de notar que em volta da nossa fogueira havia apenas o seguinte:

A um lado, o leito do rio, coberto quasi até o centro por um tapete de capim encharcado, entre o qual se viam os barris de azeite de palma amarrados, fluctuando á mercê da corrente e viração.

Para terra, desdobrava-se-nos uma vasta planicie de capim humido que, ao longe, era limitado de todas as bandas por espessos palmares e coqueiraes. Mais longe, em terceiro plano, immensas cordilheiras já de uma côr desmerecida, cujos cumes pareciam tocar nos astros com que se esbatiam n'uma confusão de azul.

Nem uma cobata! Nada que por alli perto indicasse a presença de habitantes! Alli era o senhorio exclusivo de reptis, amphibios, onças, lobos, e quiçá tigres, ainda que raros!

Reembarcámos no dongo, atrelámos os barris, e, sem mais occorrencia que n'esta mereça menção, chegámos ao Cunga, á hora exactamente em que o vapor da casa de Newton Carnigie \& C.a soltava o ultimo silvo, e jorrava as primeiras fumaradas, fazendo viagem para Loanda.

Por alguns minutos se perdeu a viagem! Não valêra o sacrificio de tantos incómmodos!

Mais oito dias de espera!... E embarcámos, eu e o meu Samba-eb, para a capital da Provincia, depois de satisfeitos e liquidados to̊dos os negocios do interior. 
Meu amigo, eis-me no limite da viagem, e de volta ao ponto de partida-Loanda.

Na posse de uma dyspepsia teimosa, complicada com doença de figado e baço, consulto os melhores medicos da localidade.

As opiniões divergem. Querem uns que eu siga para Mossamedes, outros optam pela Madeira, e alguns insistem no meu regresso a Lisboa. Noto que todos elles são conformes n'ứm ponto: e é em que eu me nã̃o posso haver bom das mi* nhas enfermidades sem mudança de clima.

Vou, em harmonia com as deliberaçẽes dos Esculapios cá da terra, retirar-me o mais breve possivel, fazendo prôa a Cabo Verde, onde ficarei, se os medicos da localidade não determinarem o contrario, em prol da minha saude.

Peço-te me desculpes a exiguidade das informações que d'aqui te tenho enviado, relevando as faltas, para encareceres, como é de justiça, a minha boa vontade de te servir.

'Teu verdudeiro amigo

\section{Ben Zacheu}

\section{Fix}


